\title{
Local and global controls on carbon isotope chemostratigraphy
}

\author{
Anne-Sofie C. Ahm¹, 2 and Jon M. Husson ${ }^{2}$ \\ ${ }^{1}$ Princeton University, Guyot Hall, Princeton, NJ 08540, USA \\ ${ }^{2}$ University of Victoria, School of Earth and Ocean Sciences, BCV8W 2Y2 Canada
}

March 10, 2021

This is a non-peer reviewed preprint submitted to EarthArXiv. The manuscript is currently in review for publication in Cambridge Elements. Please note that following peer-review, subsequent versions of this paper may have slightly different content.

${ }^{*}$ Corresponding author: aahm@princeton.edu 


\begin{abstract}
Over million-year timescales, the geologic cycling of carbon controls long-term climate and the oxidation of Earth's surface. Inferences about the carbon cycle can be made from time series of carbon isotopic ratios measured from sedimentary rocks. The foundational assumption for carbon isotope chemostratigraphy is that carbon isotope values reflect dissolved inorganic carbon in a well-mixed ocean in equilibrium with the atmosphere. However, when applied to shallow-water platform environments, where most ancient carbonates preserved in the geological record formed, recent research has documented the importance of considering both local variability in surface water chemistry and diagenesis. These findings demonstrate that carbon isotope chemostratigraphy of platform carbonate rarely represent the average carbonate sink or records changes in the composition of global seawater. Understanding what causes local variability in shallow-water settings, and what this variability might reveal about global boundary conditions, are vital questions for the next generation of carbon isotope chemostratigraphers.
\end{abstract}

\title{
1 Introduction
}

The geologic carbon cycle is central to our understanding of the evolving habitability of planet Earth. The solid Earth outgasses carbon as $\mathrm{CO}_{2}$ to the ocean-atmosphere system, and sedimentary basins bury carbon as either carbonate minerals (calcite, $\mathrm{CaCO}_{3}$, or dolomite, $\left.\mathrm{CaMg}\left(\mathrm{CO}_{3}\right)_{2}\right)$ or organic matter $\left(\mathrm{CH}_{2} \mathrm{O}\right)$. The burial of carbonate is a product of chemical weathering of igneous minerals, which generates the necessary alkalinity for carbonate mineral precipitation from seawater. Owing to a temperature-dependence of chemical reaction rates, chemical weathering (and associated carbonate burial) acts as a planetary thermostat, regulating the greenhouse gas $\mathrm{CO}_{2}$ and stabilizing global temperatures on long timescales ( $>10^{5}$ years, Walker et al. 1981). By contrast, organic matter formation is the result of biological activity. If the product of oxygenic photosynthesis, $\mathrm{CO}_{2}+\mathrm{H}_{2} \mathrm{O} \Longleftrightarrow \mathrm{CH}_{2} \mathrm{O}+\mathrm{O}_{2}$, the burial of organic carbon results in the net release of free $\mathrm{O}_{2}$ to the surface environment.

Sedimentary burial fluxes of carbon are connected both to the long-term maintenance of an equable climate (e.g., Walker et al. 1981) and the oxygenation of the surface of Earth (Broecker 1970). However, direct constraints on carbon burial fluxes, and their use to study Earth history, are rare, owing both to the difficulties in building geologic syntheses of sedimentary volumes (Ronov et al. 1980) and to the uncertainties surrounding how erosion and rock cycling have affected such records (Gregor 1970). As a result, the measurement of proxies is the dominant approach for the study of the ancient carbon cycle - specifically, the measurement of the ratio of stable carbon isotopes $\left({ }^{12} \mathrm{C}\right.$ and $\left.{ }^{13} \mathrm{C}\right)$ in carbonate rocks and sedimentary organic matter. Under specific assumptions about both how carbon behaves in the ocean-atmosphere system and how surface geochemistry is recorded in the sedimentary record, inferences about the geologic carbon cycle can be made from time series of carbon isotope ratios. These inferences include the origin of life (Schidlowski et al. 1975), transient increases in atmospheric $\mathrm{CO}_{2}$ (e.g., Berner 2006) and the burial history of organic carbon across the Phanerzoic (Broecker 1970) and Precambrian (Knoll et al. 1986). By direct consequence of this interpretative framework, carbon isotopic values can be used as tools of stratigraphic correlation. Namely, on timescales of sedimentary rock formation, perturbations and changes to the carbon cycle should be recorded in globally-disparate basins as synchronous events, and thus useful as chronostratigraphic markers for intra-basinal and inter-basinal correlation models. This application is referred to as carbon isotope chemostratigraphy, and is relied upon heavily for the study of the Precambrian, when index fossils needed for biostratigraphy are lacking (Knoll et al. 1986).

In this review, we highlight the developments, potential pitfalls, and future potentials of carbon isotope chemostratigraphy. As we explain below, the validity of its application is dependent on assumptions about the global carbon cycle, and about how the isotope geochemistry of sedimentary carbonates and organic matter records conditions of the surface environment from which 


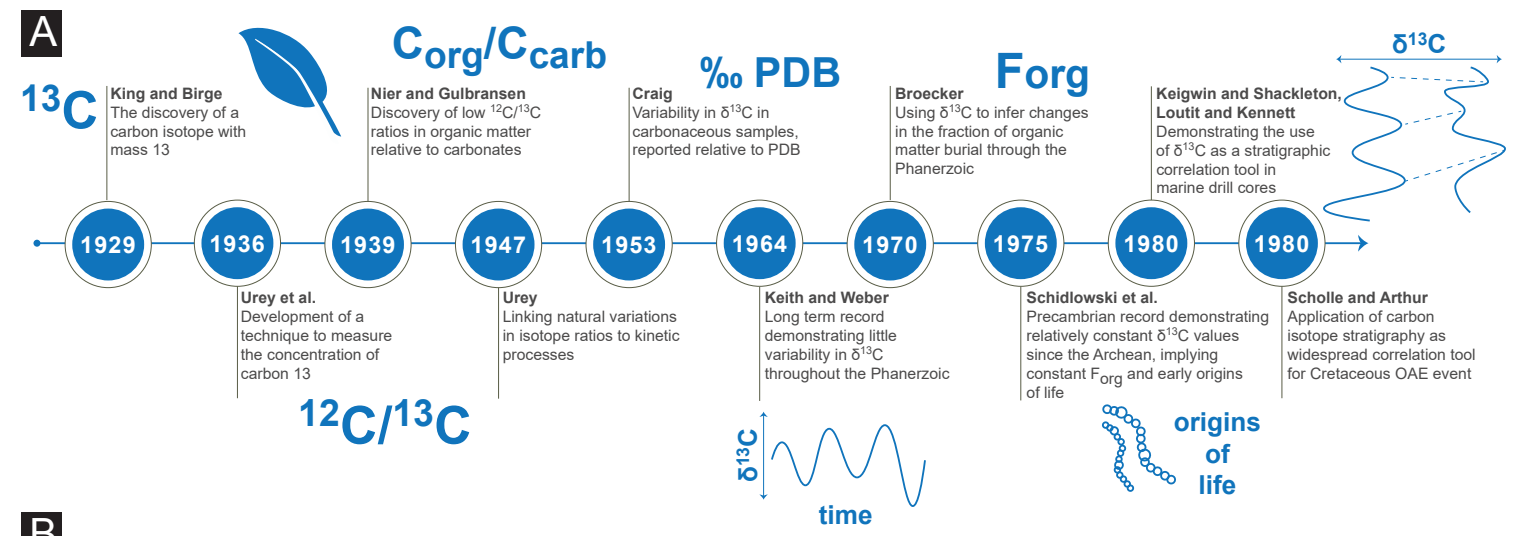

B

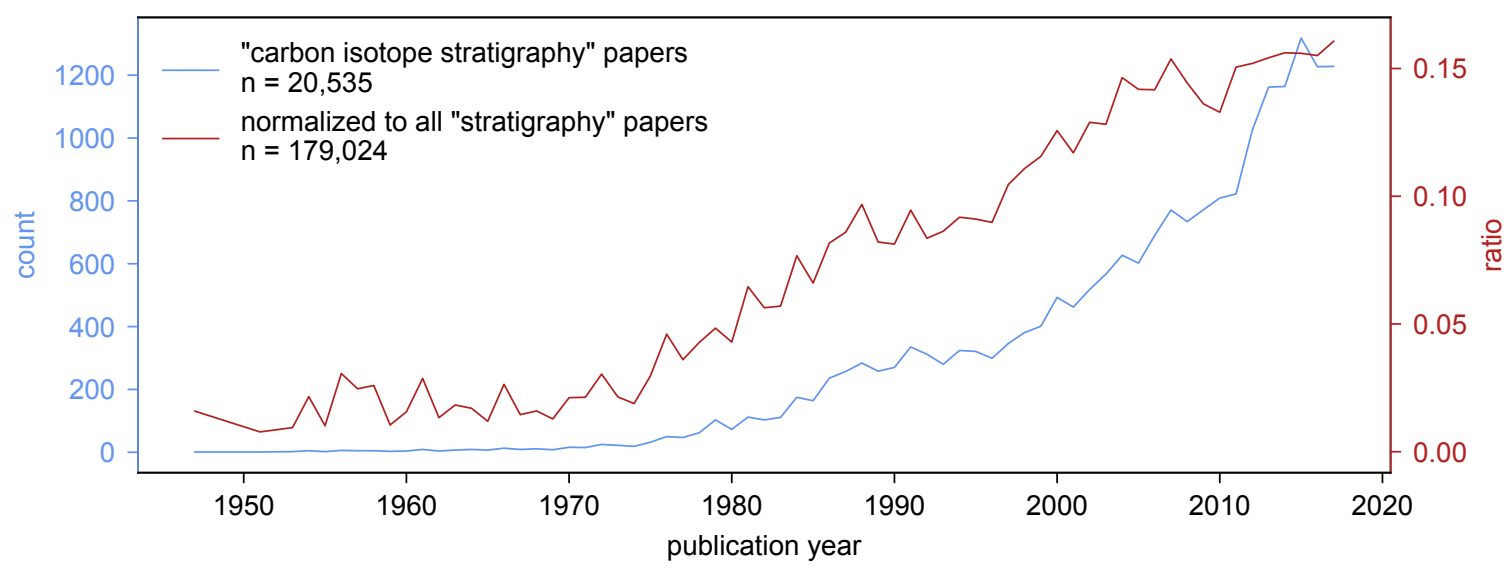

Figure 1: (A) The early history of carbon isotope research, from the discovery of ${ }^{13} \mathrm{C}$ in 1929 (King and Birge 1929) to 1980, listing some of the most consequential papers that underpin the development of carbon isotope chemostratigraphy. (B) The number of peer-reviewed papers published per year that contain the phrases 'carbon isotopes' and 'stratigraphy' (blue, left y-axis), extracted from the GeoDeepDive digital library (https://geodeepdive.org/). This record is also normalized to the yearly count of papers that contain the word 'stratigraphy' (red, right $\mathrm{y}$-axis), and shows that the acceleration in rate of published $\delta^{13} \mathrm{C}$ chemostratigraphy papers is not driven solely by a general growth in stratigraphic research. In both records, an uptick in the early 1970's is apparent, coincident with the initiation of the Deep Sea Drilling Program Data in 1968.

they formed. Of singular importance is the observation that modern shallow-water depositional systems are dominated by local carbon cycling, leading to large differences between the carbon isotope composition of modern, shallow-water $\mathrm{CaCO}_{3}$ sediment and average carbonate burial. Understanding this disconnect is important, because all sediments older than $\sim 200$ million years old formed in analogous environments, as abyssal sediments are recycled and destroyed due to seafloor spreading and subduction. Disentangling the mixture of global and local control in modern carbon isotope values is therefore vital for the interpretation of deep time records, and for the basis of carbon isotope chemostratigraphy.

\section{Systematics of carbon isotope chemostratigraphy}

\subsection{Development and history}

The groundwork for carbon isotope chemostratigraphy was laid by the pioneering research in isotope geochemistry by Alfred Nier (Nier and Gulbransen 1939) and Harold Urey (Urey et al. 1936; Urey 1947). Both made the earliest measurements of the ratios of carbon isotopes in 
natural materials by mass spectrometry (Fig. 1A). By convention, rather than discussing such values as simple ratios (e.g., ${ }^{13} R=\frac{{ }^{13} C}{12 C}$ ), carbon isotopic values are expressed in the $\delta$-notation relative to a common standard (V-PDB, Craig 1953):

$$
\delta^{13} C=\left(\frac{{ }^{13} R_{\text {sample }}}{{ }^{13} R_{\text {standard }}}-1\right) \times 10^{3}
$$

With regards to chemostratigraphy, one of most important early findings was that organic matter is depleted in ${ }^{13} \mathrm{C}$ relative to carbonate minerals (Nier and Gulbransen 1939). This discovery forms the backbone of all studies using $\delta^{13} \mathrm{C}$ values to study the carbon cycle in deep time. The first long-term record of Phanerozoic carbonate $\delta^{13} \mathrm{C}$ values was published in 1964 (Keith and Weber 1964), followed by the first continuous Precambrian record in 1975 (Schidlowski et al. 1975), both records remarking on the apparent lack of long-term variability in $\delta^{13} \mathrm{C}$ values. These observations led to the prevailing hypothesis that the burial of organic carbon (and consequentially, atmospheric oxygen levels) have been relatively stable throughout the Phanerozoic (Broecker 1970).

The later development of $\delta^{13} \mathrm{C}$ measurements as a tool for stratigraphic correlation is closely linked to the initiation of the Deep Sea Drilling Program (1968-1983, Fig. 1A). Following the success of using $\delta^{18} \mathrm{O}$ for correlation in Pleistocene and Pliocene deep sea sediment cores, carbon isotope stratigraphy was first used in the late 1970's (Fig. 1B), based on the observation of reproducible and coherent changes in $\delta^{13} \mathrm{C}$ values of carbonate (excursions of $\sim-0.5 \%$ ) in Miocene sediments across the Pacific Ocean (Loutit and Kennett 1979; Keigwin and Shackleton 1980). Contemporaneous with these developments, the observation of significant short term fluctuations - excursions - of carbonate $\delta^{13} \mathrm{C}$ values in Cretaceaous sedimentary rocks, associated with ocean anoxic events (OAEs), pushed the use of carbon isotope stratigraphy into older portions of the geologic record (Scholle and Arthur 1980). Today, numerous $\delta^{13} \mathrm{C}$ records from Cenozoic deep marine sediment cores have demonstrated systematic variations across the globe that correlate with major climatic events, used for global correlation and age model construction (e.g., Westerhold et al. 2020).

\subsection{One-box model of the carbon cycle}

At its core, carbon isotope chemostratigraphy builds on the assumption that the $\delta^{13} \mathrm{C}$ values of carbonate $\left(\delta^{13} \mathrm{C}_{\text {carb }}\right)$ reflect the $\delta^{13} \mathrm{C}$ values of dissolved inorganic carbon $\left(\delta^{13} \mathrm{C}_{D I C}\right.$, Fig. 2) in a well-mixed ocean in equilibrium with the atmosphere (Kump and Arthur 1999). In this view, independent of geographic location, all carbonate precipitated and deposited has the same value, and excursions in $\delta^{13} \mathrm{C}_{c a r b}$ will be synchronous and useful as stratigraphic tie-points between and within sedimentary basins.

The $\delta^{13} \mathrm{C}_{D I C}$ values of a well-mixed ocean in equilibrium with the atmosphere are set by the relative sizes and isotopic values of carbon sources and sinks. The primary sources of carbon to the system are weathering $\left(F_{w}\right)$, metamorphism and volcanic outgassing $\left(F_{\text {volc }}\right)$, while the sinks are burial of organic carbon $\left(F_{b, o r g}\right)$ and carbonate $\left(F_{b, c a r b}\right)$, with each flux carrying a (potentially) predictable isotopic value (Kump and Arthur 1999). Most commonly, the $\delta^{13} \mathrm{C}$ value of $\mathrm{CO}_{2}$ from volcanic and metamorphic outgassing is assumed to reflect the isotopic composition of the mantle ( $\sim-5 \%$ ) , the $\delta^{13} \mathrm{C}_{c a r b}$ value is assumed to be equal to the composition of seawater, and the $\delta^{13} \mathrm{C}_{\text {org }}$ value is assumed to be depleted in ${ }^{13} \mathrm{C}$ by approximately $\sim 25 \%$ relative to $\delta^{13} \mathrm{C}_{\text {carb }}$ (Kump and Arthur 1999; Hayes et al. 1999).

Based on the simple framework outlined above, mathematical expressions can be written for carbon mass $(M)$ and carbon isotope $\left(\delta_{D I C}\right)$ balance in the ocean-atmosphere system (Fig. 2). 

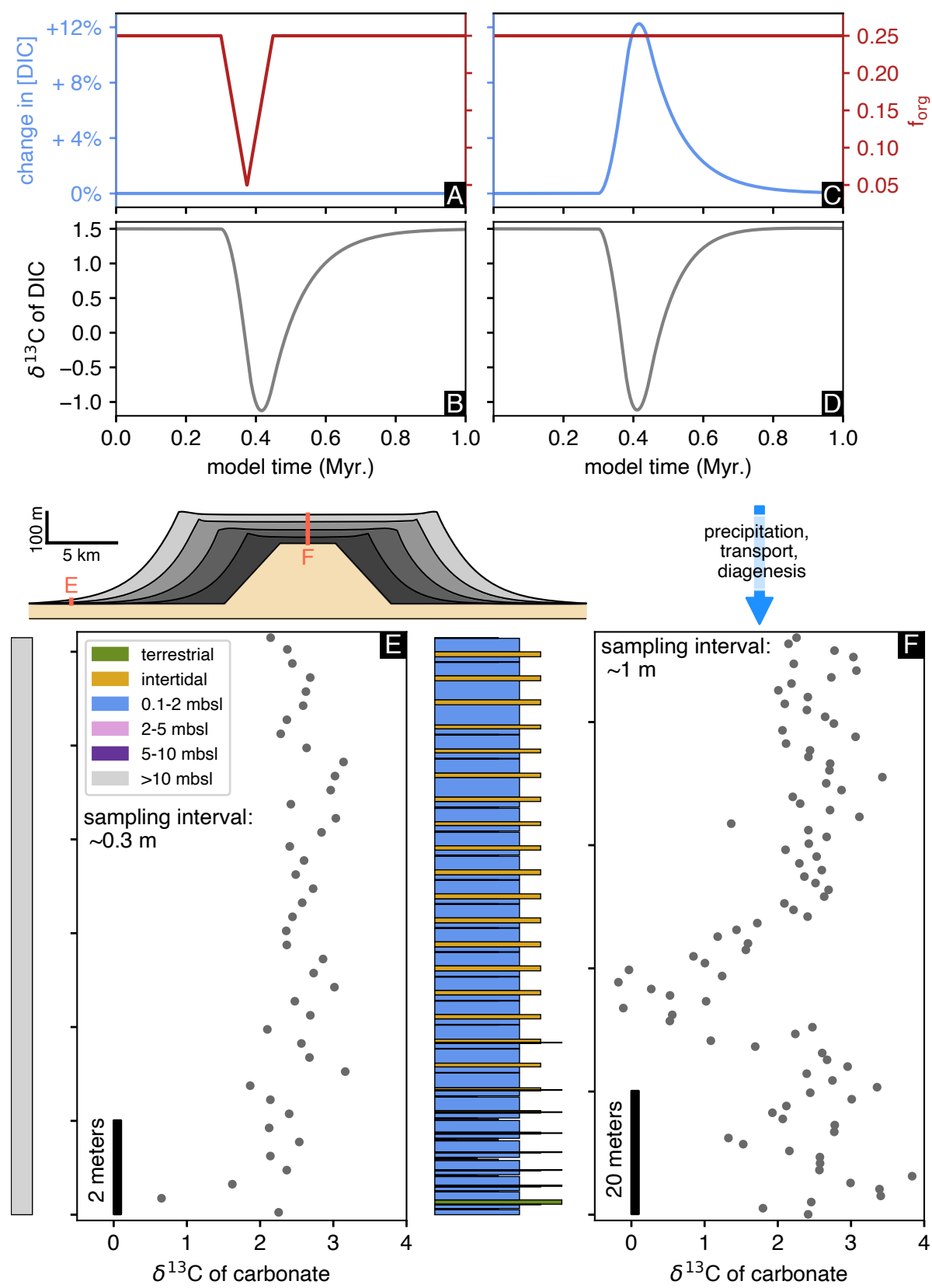

Figure 2: Toy demonstrations of carbon cycle perturbations that can be modeled using equation 5 (see section 2.2), and how these perturbations might be recorded in shallow water carbonate strata. (A, B) A transient decrease in the relative burial flux of organic carbon will result in a negative excursion in $\delta^{13} \mathrm{C}$ values of DIC. If $\mathrm{CO}_{2}$ input to the ocean-atmosphere is increased via oxidation of organic carbon, the amount of DIC would increase $(\mathbf{C})$ and an identical negative excursion can be produced $(\mathbf{D})$, but with a very different driver than in $(\mathbf{A}, \mathbf{B})$. How these seawater signals are recorded in sediments is explored with a simple numerical model of a shallow-water carbonate platform, with $\mathrm{CaCO}_{3}$ sediment production on the platform edges (e.g., fringing reefs), which is then transported via hillslope diffusion. As the platform aggrades and progrades, the proscribed $\delta^{13} \mathrm{C}_{\text {DIC }}$ signal from $(\mathbf{B})$ or $(\mathbf{D})$ is recorded with a fractionation of $1 \%$ and added "geological noise" (e.g., effects from differential mineralogy, organic matter respiration, etc.). In distal settings $(\mathbf{E})$, where all sedimentation occurs in depths $>10$ meters below sea-level (mbsl), accumulation rates are low and carbon cycle perturbations are captured poorly even with dense stratigraphic sampling. In platform interior settings $(\mathbf{F})$, accumulation rates are higher, and the resulting $\delta^{13} \mathrm{C}_{\text {carb }}$ record is expanded. 
The change in the mass of carbon in the system through time $\left(\frac{d M}{d t}\right)$ equals the balance between sources and sinks:

$$
\frac{d M}{d t}=F_{w}+F_{\text {volc }}-F_{b, o r g}-F_{b, c a r b}
$$

By the same logic, isotope mass balance can be treated if each flux or reservoir is multiplied by its respective $\delta^{13} \mathrm{C}$ value:

$$
\frac{d M \delta_{D I C}}{d t}=\delta_{w} F_{w}+\delta_{\text {volc }} F_{\text {volc }}-\delta_{\text {org }} F_{b, \text { org }}-\delta_{\text {carb }} F_{b, c a r b}
$$

By rearranging these equations using the product rule of calculus $(d M \delta / d t=M * d \delta / d t+\delta *$ $d M / d t)$, it is possible to isolate $d \delta / d t$ and derive a time-dependent differential equation for ocean $\delta^{13} \mathrm{C}_{D I C}$ values:

$$
\frac{d \delta_{D I C}}{d t}=\frac{F_{w}\left(\delta_{w}-\delta_{D I C}\right)+F_{v o l c}\left(\delta_{v o l c}-\delta_{D I C}\right)-F_{b, o r g}\left(\delta_{b, \text { org }}-\delta_{D I C}\right)-F_{b, c a r b}\left(\delta_{b, c a r b}-\delta_{D I C}\right)}{M}
$$

This expression typically is simplified further by making three assumptions (Kump and Arthur 1999). First, the $\delta^{13} \mathrm{C}$ value of carbonate is set equal to the value of DIC $\left(\delta_{D I C}=\delta_{\text {carb }}\right)$. Second, the input fluxes from weathering and volcanic outgassing are merged into a single input flux from rivers $\left(F_{\text {riv }}\right)$. Third, the $\delta^{13} \mathrm{C}$ value of organic carbon is defined by an average offset from carbonate $\left(\Delta_{B}=\delta_{\text {org }}-\delta_{\text {carb }}\right)$. We explore the validity of these assumptions in more detail below (section 3), but they can be used to simplify equation 4 to:

$$
\frac{d \delta_{c a r b}}{d t}=\frac{F_{r i v}\left(\delta_{r i v}-\delta_{c a r b}\right)-F_{b, o r g} * \Delta_{B}}{M}
$$

This box model approach (equation 5) shows that the $\delta^{13} \mathrm{C}$ value of the global ocean (and, by extension, that of buried marine carbonate) may evolve with time through numerous forcings, with different processes often generating the same $\delta_{\text {carb }}$ time series. For example, total carbon input $\left(F_{\text {riv }}\right)$ and burial $\left(F_{b, c a r b}+F_{b, o r g}\right)$ fluxes can remain equal, while the ratio of $F_{b, \text { org }}$ relative to $F_{b, c a r b}$ may decrease. In this scenario, $M$ will remain the same but $\delta^{13} \mathrm{C}$ of DIC will fall (Fig. 2A-B). Transient imbalances in the mass fluxes of carbon can lead to changes in both $M$ and $\delta^{13} \mathrm{C}_{D I C}$ : oxidation of a large pool of organic carbon $\left(\delta^{13} \mathrm{C} \approx-25 \%\right)$ will increase ocean DIC concentration and will lower its $\delta^{13} \mathrm{C}$ value (Fig. $\left.2 \mathrm{C}-\mathrm{D}\right)$.

When considering time scales much longer than the residence time of carbon in the oceanatmosphere system ( $>10^{5}$ years), the carbon cycle box model is in a steady state, and the input and output mass fluxes must balance each other. In this scenario, equation 5 can be further simplified by setting $d \delta_{\text {carb }} / d \delta_{t}=0$ and setting the input flux of carbon equal to the burial fluxes $\left(F_{\text {riv }}=F_{b, o r g}+F_{b, c a r b}\right)$ :

$$
\frac{F_{\text {org }}}{F_{\text {org }}+F_{\text {carb }}}=\frac{\delta_{\text {riv }}-\delta_{\text {carb }}}{\Delta_{B}}=f_{\text {org }}
$$

The burial fraction of organic carbon $\left(F_{\text {org }}\right)$ relative to total carbon burial $\left(F_{\text {org }}+F_{\text {carb }}\right)$ is commonly abbreviated in the literature as $f_{\text {org }}$ (Fig. $2 \mathrm{~A}$ and C). Equation 6 demonstrates that if we know both the average isotope offset between organic matter and carbonate (e.g., $\Delta_{B}=-25 \%$, Hayes et al. 1999) and the average isotopic value of the carbon input flux ( $\delta_{\text {riv }}$, assumed to equal the mantle value of $\sim-5 \%$ ), then it is possible to calculate $f_{\text {org }}$ (Kump and Arthur 1999). By 
illustration, if $\delta_{\text {carb }}$ is set to the modern DIC value of $\sim 0 \%$, then $f_{\text {org }}$ is 0.2 , implying that on Earth today $20 \%$ of the carbon sink is organic carbon burial and $80 \%$ is carbonate burial.

This hypothesis that $\delta^{13} \mathrm{C}_{c a r b}$ values can be directly linked to oxygen production by estimating the relative burial flux of organic carbon $\left(f_{\text {org }}\right)$ is widely used to interpret deep time $\delta^{13} \mathrm{C}_{\text {carb }}$ records, both in the Precambrian (e.g., Knoll et al. 1986; Kaufman et al. 1997; Canfield et al. 2020) and Phanerozoic (e.g., Broecker 1970; Saltzman 2005; Berner 2006). To apply this framework, it is assumed that $\delta^{13} \mathrm{C}_{c a r b}$ values measured across several stratigraphic columns are representative of the average carbonate burial sink and that stratigraphic trends in $\delta^{13} \mathrm{C}_{c a r b}$ represent secular changes in the global carbon cycle. Below we examine this assumption more closely. Specifically, we investigate the effects of local isotopic variability on stratigraphic records of $\delta^{13} \mathrm{C}_{\text {carb }}$ and the implications for global mass balance.

\section{Local controls and issues of fidelity and diagenesis}

In theory, according to the model frame work developed above, time series of $\delta^{13} \mathrm{C}$ values of either carbonate or organic carbon can be used to reconstruct global ocean $\delta^{13} \mathrm{C}_{D I C}$ values. In practice, $\delta^{13} \mathrm{C}$ of carbonate $\left(\delta^{13} \mathrm{C}_{c a r b}\right)$ are far more common, owing in large part to the high throughput capabilities of sample preparation and modern instrumentation. When interpreting $\delta^{13} \mathrm{C}$ records in terms of the global carbon cycle (e.g., equations 5 and 6 ), the important question is: does the record capture a representative $\delta^{13} \mathrm{C}$ value of average carbonate burial? For Cenozoic deep-marine $\delta^{13} \mathrm{C}$ records, datasets can be collected that cover large geographical areas of the deep ocean sea floor and, when stacked in time bins, are likely to satisfy this constraint (e.g., Westerhold et al. 2020). By contrast, the chemostratigraphic records from shallow-water settings, such as carbonate platforms or epeiric seas, are complicated by a much larger range in $\delta^{13} \mathrm{C}_{c a r b}$ values owing to local carbon cycling (Fig. 3, Holmden et al. 1998).

Today, it is accepted that the average $\delta^{13} \mathrm{C}_{c a r b}$ value of carbonate forming on shallow-water platforms does not represent the $\delta^{13} \mathrm{C}_{c a r b}$ value of average carbonate burial, even when integrated across the globe (Swart 2008). Prior to the evolution of a deep-marine carbonate sink in the mid-Mesozoic, carbonate platforms likely played a bigger role in the global carbonate burial budget (Opdyke and Wilkinson 1988), meaning that average platform $\delta^{13} \mathrm{C}_{c a r b}$ would have been closer (or equal) to globally average carbonate $\delta^{13} \mathrm{C}$. As a result, following the approach from the Cenozoic, a hypothesis for the pre-Mesozoic is that changes in the global carbon cycle can be evaluated by collecting correlative chemostratigraphic records of $\delta^{13} \mathrm{C}$ values across several continents. However, even when independent tools such as biostratigraphy or geochronology are available for correlation, the timescales for perturbations to the global carbon cycle $\left(<10^{5}\right.$ years, Fig. 2A-D) are challenging to resolve for even the best chronostratigraphic age models (Schoene 2014; Holland 2020), especially for pre-Mesozoic strata.

Thus, if shallow-water carbon successions are only broadly correlative (e.g., at the $0.5-5$ million year level), or only recorded in a subset of basins globally, apparent excursions in $\delta^{13} \mathrm{C}_{\text {carb }}$ values could easily represent local processes rather than global perturbations (Fig. 2E,F). Given these uncertainties, how variability in $\delta^{13} \mathrm{C}$ values in shallow-water environments can be expressed in stratigraphic records on local, regional, and global scales is vitally important for $\delta^{13} \mathrm{C}$ chemostratigraphy (Fig. 3).

\subsection{Local variability in carbon sources and sinks}

Riverine input: One of the main sources of DIC to shallow-water environments is the discharge of rivers and groundwater to coastal settings (Fig. 3). Contrary to the assumptions made above, concerning a single isotopic value for riverine input $\left(F_{r i v}\right.$, equation $\left.5-6\right)$, there 


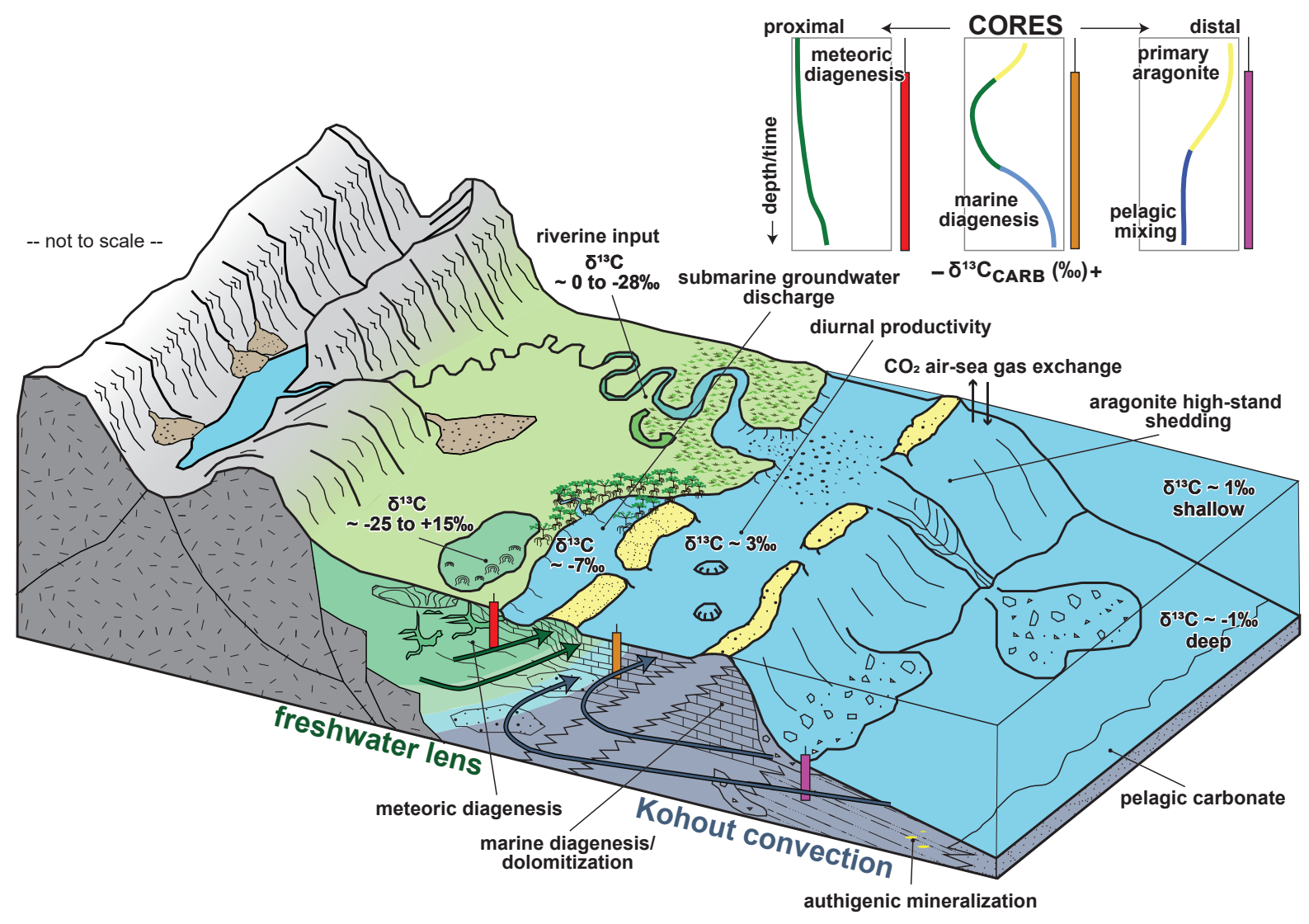

Figure 3: Schematic illustrating the variability in surface water $\delta^{13} \mathrm{C}$ across different depositional environments in carbonate platform or epeiric sea settings (see text in section 3 for description of each environment). Values of $\delta^{13} \mathrm{C}$ refer to dissolved inorganic carbon (DIC), unless stated otherwise. Core profiles illustrate the coincident variability in bulk carbonate $\delta^{13} \mathrm{C}$ that can be expected as products of local surface water chemistry and carbonate diagenesis.

is a large range in the concentration and isotopic composition of DIC from rivers (even if the average value is well constrained). As one example, streams in Sweden yielded $\delta^{13} \mathrm{C}_{D I C}$ values ranging between -28 to $0 \%$ (Campeau et al. 2017). This range is a product of upstream soil respiration, local mixtures of carbonate and organic carbon weathering, and variable degrees of stream water DIC equilibration with atmospheric $\mathrm{CO}_{2}$. In general, rivers with low $\delta^{13} \mathrm{C}_{D I C}$ values often are associated with siliciclastic-dominated catchments with high degrees of organic carbon respiration, while higher $\delta^{13} \mathrm{C}_{D I C}$ values often are associated with carbonate-dominated catchments (Khadka et al. 2014).

The difference in $\delta^{13} \mathrm{C}_{D I C}$ values between siliciclastic- and carbonate-dominated rivers may be important to consider when interpreting the stratigraphic trends of $\delta^{13} \mathrm{C}_{\text {carb }}$ in mixed carbonatesiliciclastic depositional systems (e.g., Rodriguez Blanco et al. 2020). On carbonate platforms, adjacent to continental blocks, deposition is influenced by the clastic sediment and nutrient influx from river drainage systems that migrate over time. The chemostratigraphic implications of such a depositional setting is that $\delta^{13} \mathrm{C}$ values of carbonate that precipitates in coastal waters may vary as a function of local siliciclastic input. It may be possible to disentangle this effect by linking sedimentological facies observations with $\delta^{13} \mathrm{C}_{c a r b}$ values (Rodriguez Blanco et al. 2020). However, while the influx of siliciclastic material largely is controlled by local fluvialdeltaic processes, it is possible that global climate and/or eustatic sea-level change can generate widespread changes in relative weathering of carbonate versus siliciclastic material (Harper et al. 
2015). For example, increased weathering and diagenesis of carbonate platforms during glacial sea-level lowstands would likely increase the $\delta^{13} \mathrm{C}$ value of global riverine inputs (Kump et al. 1999; Dyer et al. 2015). Alternatively, increased weathering and remineralization of organic-rich sediments may increase the input flux of ${ }^{13} \mathrm{C}$ depleted carbon and decrease the surface ocean $\delta^{13} \mathrm{C}_{D I C}$ value (Fig. $2 \mathrm{C}, \mathrm{D}$ ). While possibly global in scale, the impact of changes in riverine weathering fluxes are easily amplified in shallow-water platforms and epeiric seas (e.g., Holmden et al. 1998).

Submarine groundwater discharge: In additional to riverine input, submarine groundwater discharge also has measurable effects on surface water $\delta^{13} \mathrm{C}_{D I C}$ values in coastal areas (Fig. 3). For example, in Florida Bay and the Little Bahama Banks, submarine groundwater discharge leads to surface water $\delta^{13} \mathrm{C}_{D I C}$ values down to $-7 \%$ (Patterson and Walter 1994). These low values are a product of organic carbon respiration in the freshwater aquifer that flows towards the sea from platform interiors. In some coastal areas, such as in mangrove-dominated tidal creeks and reefs, the flux of groundwater discharge varies with the tides, with the highest inputs of groundwater at low tide, which results in high creek DIC concentrations $(>3 \mathrm{mmol} / \mathrm{kg}$, Maher et al. 2013). Surface water $\delta^{13} \mathrm{C}_{D I C}$ values vary by up to $10 \%$ across a tidal cycle, from $-8 \%$ at low tide to $+2 \%$ at high tide (Maher et al. 2013). However, it is unlikely that the entire range in $\delta^{13} \mathrm{C}_{D I C}$ is captured by carbonate precipitation, as the carbonate saturation state $\left(\Omega=\left\{\mathrm{Ca}^{2+}\right\} *\left\{\mathrm{CO}_{3}^{2-}\right\} / K_{s p}\right.$, where $K_{s p}$ is the solubility product for aragonite) is also lowered with the input of respired and dissolved $\mathrm{CO}_{2}$, thus predicting less precipitation during periods of high submarine groundwater discharge and low $\delta^{13} \mathrm{C}_{D I C}$.

Despite the potential lack of carbonate mineral precipitation at times of very low $\delta^{13} \mathrm{C}_{D I C}$, stratigraphic records from carbonate platforms may still preserve $\delta^{13} \mathrm{C}_{c a r b}$ signals that are modified by local submarine groundwater discharge. For example, if local discharge into coastal environments carries significant amounts of dissolved carbonate in solution, positive $\delta^{13} \mathrm{C}$ ' $\mathrm{ex}$ cursions' can be created in carbonate precipitating from these waters (Holmden et al. 2012).

Diurnal productivity: Dissolved inorganic carbon in coastal areas can exhibit large diurnal fluctuations in $\delta^{13} \mathrm{C}_{D I C}$ values, driven by day-time photosynthesis and night-time respiration of organic matter (Fig. 3). For example, surfaces waters in reefs on O'ahu show a range in $\delta^{13} \mathrm{C}_{D I C}$ values of up to $5 \%$ across a diurnal cycle (Richardson et al. 2017). In such settings, carbonate precipitation occurs predominantly during the most productive parts of the diurnal cycle, recording $\delta^{13} \mathrm{C}_{\text {carb }}$ values up to $+7 \%$ in platform aragonite (Geyman and Maloof 2019). This pattern is due to the respiration of organic carbon at night-time, lowering $\Omega$ and hindering carbonate precipitation. As a result, stratigraphic records from shallow-water environments may be biased towards higher $\delta^{13} \mathrm{C}_{c a r b}$ values relative to average surface water $\delta^{13} \mathrm{C}_{D I C}$. If shallow platforms contribute significantly to the global carbon budget then, as the relative area of shallow shelves increases, the burial of ${ }^{13} \mathrm{C}$-enriched carbonate will lower the average seawater $\delta^{13} \mathrm{C}_{D I C}$ to satisfy global mass balance (Geyman and Maloof 2019).

Air-sea gas-exchange: Highly variable $\delta^{13} \mathrm{C}_{D I C}$ values of shallow-water environments are possible due to slow rates of air-sea gas exchange, meaning that surface water $\delta^{13} \mathrm{C}_{D I C}$ can diverge from equilibrium values with the overlying atmosphere (Lynch-Stieglitz et al. 1995). The exchange of $\mathrm{CO}_{2}$ across the air-sea interface is also associated with kinetic isotope effects, with the preferential dissolution and degassing of ${ }^{12} \mathrm{C}$ (e.g., Wanninkhof 1985). Surface waters that have low DIC concentrations with net $\mathrm{CO}_{2}$ invasion may therefore have lower $\delta^{13} \mathrm{C}_{D I C}$ values compared to surface waters with high DIC concentration and net $\mathrm{CO}_{2}$ degassing (Wanninkhof 1985). The isotope effects of air-sea gas exchange can dampen the $\delta^{13} \mathrm{C}_{D I C}$ enrichment from the biological pump in surface waters, but in the modern ocean these kinetic effects are 
relatively small, leading to spatial variability in surface waters $\delta^{13} \mathrm{C}_{D I C}$ of the open ocean of up to $2 \%$ (Lynch-Stieglitz et al. 1995)

In contrast to the modern surface-ocean, kinetic isotope effects associated with $\mathrm{CO}_{2}$ exchange can be pronounced in hypersaline and restricted environments (e.g., Lazar and Erez 1992; Clark et al. 1992; Beeler et al. 2020). In these settings, carbonate with $\delta^{13} \mathrm{C}$ values between -25 and $+15 \%$ have been documented (Fig. 3), with rapid invasion of $\mathrm{CO}_{2}$ leading to low $\delta^{13} \mathrm{C}_{c a r b}$ values (Clark et al. 1992) and degassing of $\mathrm{CO}_{2}$ leading to high $\delta^{13} \mathrm{C}_{c a r b}$ values (Beeler et al. 2020). It is unclear if kinetic effects are expressed in stratigraphic $\delta^{13} \mathrm{C}_{c a r b}$ records, but it has been suggested that these processes may have been more pronounced in Precambrian platform environments, where abiotic or microbially-mediated carbonate precipitation likely was more important (Ahm et al. 2019; Husson et al. 2020).

Redox and authigenic mineralization: In both shallow and deep marine settings, ${ }^{13} \mathrm{C}_{\text {carb }}$ values may be influenced by anoxic remineralization of organic carbon and consequent precipitation of in-situ (authigenic) carbonate in the sediment pore-space (Fig. 3). More specifically, methanogenesis (methane production) and sulfate reduction within the sediment pile may lead to the precipitation of authigenic carbonate with extreme $\delta^{13} \mathrm{C}_{c a r b}$ values. Methane $\left(\mathrm{CH}_{4}\right)$ has very low $\delta^{13} \mathrm{C}$ values ( -60 to $-80 \%$, Claypool and Kaplan 1974), meaning that its production leaves residual porewater DIC with heavy $\delta^{13} \mathrm{C}$ values. In contrast to oxic respiration of organic matter, which lowers pore-water $\Omega$ values and promotes carbonate dissolution, anoxic respiration (such as sulfate reduction) tends to increase $\Omega$ and rates of carbonate precipitation (Claypool and Kaplan 1974). For example, methane oxidation by sulfate reduction has been shown to produce carbonate cements with $\delta^{13} \mathrm{C}_{\text {carb }}$ values down to $-56 \%$ (Hovland et al. 1987). In contrast, $\delta^{13} \mathrm{C}_{\text {carb }}$ values up to $+16 \%$ has been documented in stromatolitic and microbial carbonate as the result of methanogenesis (Birgel et al. 2015). However, whether authigenic carbonate formation is a significant carbonate sink with the potential to influence global $\delta^{13} \mathrm{C}_{D I C}$ values has been a source of debate throughout the last decade (Bjerrum and Canfield 2004; Higgins et al. 2009; Schrag et al. 2013; Canfield et al. 2020).

\subsection{Carbonate mineralogy, fractionation, and mixing}

The $\delta^{13} \mathrm{C}$ value of carbonate is fractionated relative to local surface water DIC, with the preferential uptake of ${ }^{13} \mathrm{C}$ into the carbonate mineral lattice (contrary to the assumption in equation 5 that $\left.\delta_{D I C}=\delta_{\text {carb }}\right)$. The magnitude of fractionation varies for different carbonate polymorphs. Aragonite is more enriched in ${ }^{13} \mathrm{C}(\sim 3 \%)$ compared to calcite ( $\sim 1 \%$, Romanek et al. 1992). As a result, stratigraphic changes in $\delta_{\text {carb }}$ can be produced by the mixing of aragonite, which is predominantly made in shallow-water carbonate factories like The Bahamas (Lowenstam and Epstein 1957), and calcite, the dominant polymorph of pelagic calcifiers (Bown et al. 2004). For example, it is possible to generate systematic changes in the relative fractions of platform versus pelagic derived carbonate during periods of sea-level change, which may lead to coherent and reproducible stratigraphic changes in $\delta^{13} \mathrm{C}$ values that are decoupled from changes to the global carbon cycle (see Case Study below, Swart and Eberli 2005; Swart 2008). Mixing of calcite and aragonite end-members, even if both formed from the same fluid and DIC pool, can also lead to "noise" in the stratigraphic $\delta^{13} \mathrm{C}_{\text {carb }}$ record (e.g., Fig. 2E,F).

In addition to the mineralogical differences in carbon isotope fractionation, there is considerable variability in isotopic values of organic matter and, hence, local differences in $\Delta_{B}$ (equations 5 and 6, Hayes et al. 1999). The range of isotopic values of organic matter are related to organismal growth rates and the specific carbon fixation pathways employed (Pearson 2010). First, species-specific fractionation results in a large isotopic range where, for example, terrigenous, coastal, and marine organic carbon can be offset by up to 20\% (Oehlert et al. 2012). Second, 
the net fractionation factor between local surface water DIC and organic carbon $\left(\Delta_{B}\right)$ is dependent upon the concentration of $\mathrm{CO}_{2}$ in the ambient environment (Popp et al. 1998), with higher $\mathrm{CO}_{2}$ levels leading to a more negative fractionation (reflecting preferential uptake of ${ }^{12} \mathrm{C}$ ). These isotope effects are relevant to consider in shallow-water coastal environments where DIC concentrations (and hence ambient $\mathrm{CO}_{2}$ ) vary on semi-diurnal and diurnal timescales (see above).

Differences in isotopic fractionation of organic matter can be recorded by chemostratigraphy, since the bulk isotopic composition of organic carbon at a given locality will reflect the relative input of different sources (Fig. 3). In coastal environments, especially, these inputs can be highly variable both in space and time, with transport and deposition of sediments from coastal environments into deeper waters causing stratigraphic changes in $\delta^{13} \mathrm{C}$ values of both carbonate and organic carbon due to mixing (Oehlert et al. 2012; Oehlert and Swart 2014).

\subsection{Carbonate diagenesis}

As carbonate sediments are buried and lithified, they pass through several stages of diagenesis (e.g., meteoric, marine, burial), where primary metastable carbonate minerals dissolve and diagenetic minerals precipitate. The most common approach for predicting whether the isotopic value of given element (e.g., C, O, Ca, trace metals) will be reset during lithification is to consider the comparative abundances of that element in altering fluids and in the sediment (Banner and Hanson 1990). If an element has low abundance in the fluid relative to the sediment (such as for carbon in seawater compared to $\mathrm{CaCO}_{3}$ sediment), the sediment is more likely to retain its original isotopic composition (sediment-buffered diagenesis). However, in settings with high fluid flow rates (advection dominated), the cumulative fluid-to-rock ratio for carbon becomes high and the isotopic composition of the primary carbonate sediment can be reset (fluid-buffered diagenesis). Fluid-buffered diagenetic regimes are common in shallow-water and peri-platform environments where flow rates are high and largely driven by buoyancy and geothermal convection (Fig. 3, $\sim 10 \mathrm{~cm} / \mathrm{yr}$, Henderson et al. 1999; Kohout 1965). In contrast, sediment-buffered diagenesis occurs in settings where fluid flow rates are low (diffusion dominated) or in settings with low fluid carbon concentrations. During sediment-buffered diagenesis, the isotopic composition of the pore-fluid is in equilibrium with the sediment and does not have the potential to alter $\delta^{13} \mathrm{C}_{\text {carb }}$ values. Sediment-buffered diagenesis is characteristic of the deep ocean seafloor where subsurface fluid flow is diffusion dominated (e.g., Fantle et al. 2010) or during late-stage burial diagenesis where pore-fluid tends to have reacted extensively with the host strata. As a result, if $\delta^{13} \mathrm{C}$ values are reset, this process likely occurs relatively early, within the first $100 \mathrm{~s}$ meter below the seafloor, at burial temperatures $<40^{\circ} \mathrm{C}$ (Staudigel and Swart 2019; Murray et al. 2021).

Calcium isotopes: Other geochemical proxies can be measured along with $\delta^{13} \mathrm{C}_{\text {carb }}$ to evaluate the degree of diagenetic alteration (e.g., carbonate $\delta^{18} \mathrm{O}$ and $\mathrm{Mn} / \mathrm{Sr}$ measurements). More recently, calcium isotopes $\left(\delta^{44 / 40} \mathrm{Ca}\right)$ has emerged as a powerful tool for disentangling the degree of fluid versus sediment-buffered diagenesis of $\delta^{13} \mathrm{C}_{\text {carb }}$ values. The advantage of carbonate $\delta^{44 / 40} \mathrm{Ca}$, in comparison to $\delta^{18} \mathrm{O}$ values for example, is that the ratio of calcium in carbonate minerals relative to seawater is similar to that of carbon, which means that the two isotopic systems respond to diagenesis at similar fluid-to-rock ratios (Fantle and Higgins 2014; Ahm et al. 2018). Combining $\delta^{13} \mathrm{C}_{\text {carb }}$ values with both $\delta^{44 / 40} \mathrm{Ca}$ and $\mathrm{Sr} / \mathrm{Ca}$ ratios can fingerprint different diagenetic end-members (Fig. $4 \mathrm{C}-\mathrm{D}$ ). This tool is useful because Ca isotope fractionation and $\mathrm{Sr}$ partitioning is sensitive to both carbonate mineralogy and precipitation rate (Tang et al. 2008; Gussone et al. 2005). Primary aragonite is more depleted in ${ }^{44} \mathrm{Ca}$ and enriched in $\mathrm{Sr}$ (with values 
of $-1.5 \%$ and $10 \mathrm{mmol} / \mathrm{mol}$, respectively) relative to primary calcite $(-1 \%$ and $\sim 1 \mathrm{mmol} / \mathrm{mol})$. Diagenetic calcite or dolomite is characterized by lower Sr contents $(<1 \mathrm{mmol} / \mathrm{mol})$ and less fractionated $\delta^{44 / 40} \mathrm{Ca}$ values, approaching $\sim 0 \%$ at equilibrium with the pore-fluids (Fantle and DePaolo 2007; Jacobson and Holmden 2008). As a result, sediment-buffered diagenesis will be labeled by low $\delta^{44 / 40} \mathrm{Ca}$ values and relatively high $\mathrm{Sr} / \mathrm{Ca}$ ratios, while fluid-buffered diagenesis will be labeled by high $\delta^{44 / 40} \mathrm{Ca}$ values and low Sr/Ca ratios (Fig. $4 \mathrm{C}-\mathrm{D}$, Higgins et al. 2018).

In addition to helping identify primary and diagenetic end-members, $\delta^{44 / 40} \mathrm{Ca}$ values can also shed light on the degree to which geographically disparate carbonate successions, which often are correlated using carbon isotope chemostratigraphy (especially in the Precambrian), reflect the globally-averaged carbonate sink (Blättler and Higgins 2017). The main $\mathrm{Ca}^{2+}$ sink from the ocean is the burial of carbonate. Thus, a prediction for the global calcium cycle is that when in a steady state, the globally-averaged calcium isotope composition of carbonate sediments should equal that of bulk silicate Earth $\left(\sim-1 \%\right.$ on time-scales $>10^{6}$ years, Skulan et al. 1997; Blättler and Higgins 2017). In other words, if the Ca cycle is in steady state, the $\delta^{44 / 40} \mathrm{Ca}$ of the average carbonate sink has a predictable value $(\sim-1 \%$ ). Calcium isotopes can therefore be used not only to understand diagenesis, but when averaged across the global, may also be used to evaluate if correlated stratigraphic sections reflect the average carbonate burial sink. For example, in scenarios where negative $\delta^{13} \mathrm{C}$ values correlate with $\delta^{44 / 40} \mathrm{Ca}$ values more negative than bulk silicate Earth across several stratigraphic sections, mass balance requires that other carbonate sinks must exist that record more positive $\delta^{44 / 40} \mathrm{Ca}$ values (e.g., authigenic cements, hydrothermal veins, or dolomitized carbonate platforms, Gussone et al. 2020). While it is not necessary that the $\delta^{13} \mathrm{C}$ values of these unmeasured carbonates also are positive, it is uncertain that the globally-average carbonate sink does have a negative $\delta^{13} \mathrm{C}$ value, and these values do not need to be tracking the global carbon cycle. The alternative scenario, where several stratigraphic sections with negative $\delta^{13} \mathrm{C}$ values also coincide with an average $\delta^{44 / 40} \mathrm{Ca}$ value of $\sim-1 \%$, strengthens the argument for interpreting carbon isotope values in terms of global carbon fluxes (e.g., Fig. 2A-D).

On shorter time scales, within the residence time of calcium in the ocean $\left(<10^{6}\right.$ years), it is possible to have excursions in $\delta^{44 / 40} \mathrm{Ca}$ values that reflect transient imbalances in calcium inputs and outputs. In this scenario, it is possible to have $\delta^{13} \mathrm{C}$ and $\delta^{44 / 40} \mathrm{Ca}$ excursions that correlate across the globe. Numerical models that include the coupled carbon- $\mathrm{CaCO}_{3}$ cycle have demonstrated that the maximum transient $\delta^{44 / 40} \mathrm{Ca}$ excursion that can occur from the combined effects of increased weathering (which can increase global ocean Ca concentration) and ocean acidification (which can depress $\mathrm{CaCO}_{3}$ burial) is $\sim-0.3 \%$ (Komar and Zeebe 2016). There are two implications for carbon isotope chemostratigraphy. First, if a $\delta^{13} \mathrm{C}$ excursion correlates with a $\delta^{44 / 40} \mathrm{Ca}$ excursion, then the duration of these excursions must be $<10^{6}$ years (if Ca residence time is similar to the modern). Second, the magnitude of change in $\delta^{44 / 40} \mathrm{Ca}$ values has to be $<0.3 \%$. If either is not true, then the excursions are difficult to interpret in terms of the global $\mathrm{C}$ and $\mathrm{Ca}$ cycles, indicating that local controls are most important for $\delta^{44 / 40} \mathrm{Ca}$ and $\delta^{13} \mathrm{C}$ values (Fig. 3 ).

In the next section, we highlight case-studies that demonstrate the potential to disentangle global and local processes using a combination of carbonate $\delta^{44 / 40} \mathrm{Ca}$ and $\delta^{13} \mathrm{C}$ values.

\section{Case studies}

\subsection{The Great Bahamas Bank}

The Bahamas Drilling Project and the Ocean Drilling Program (ODP Leg 166), acquired a transect of cores across the Great Bahamas Bank west of Andros Island, including the platform 

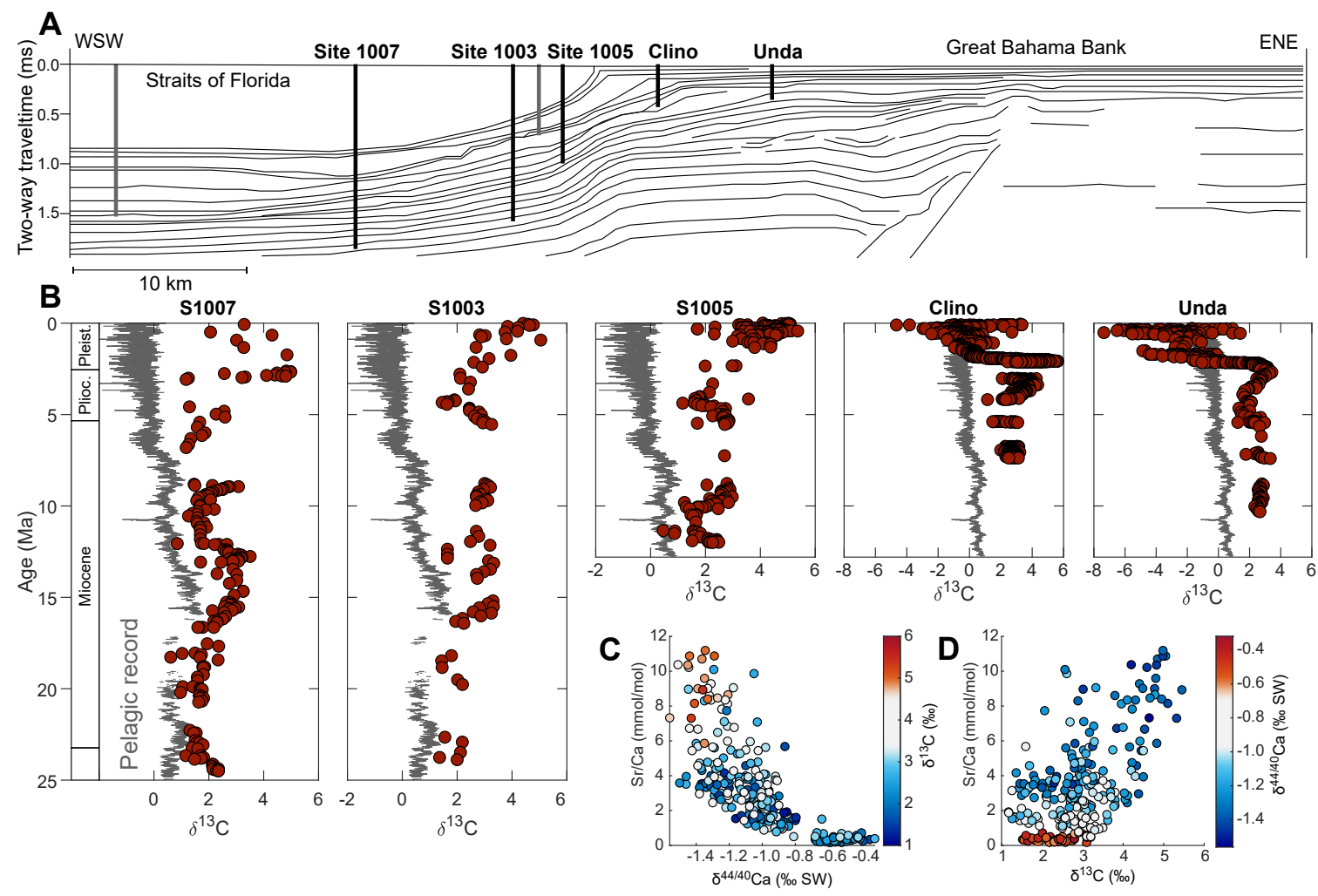

Figure 4: The variability in $\delta^{13} \mathrm{C}_{c a r b}$ values from the Bahamas Transect $(\mathbf{A})$, in cores taken across the bank-top and peri-platform slope, differ from the trends observed in deep-sea pelagic records (gray line, Westerhold et al. 2020). (B) Across the Bahamas transect (Eberli et al. 1997; Ginsburg 2001), the downcore trends are products of early marine diagenesis, meteoric alteration, and mixing between platform aragonite $\left(\delta^{13} \mathrm{C} \sim 6 \%\right.$ o $)$ and pelagic carbonate $\left(\delta^{13} \mathrm{C} \sim 1 \%\right.$ ) . Notably, in peri-platform cores (S1007, S1005, S1003) the increasing trends in $\delta^{13} \mathrm{C}$ across the Plio-Pleistocene are also observed in platforms across the world (Swart 2008), and record mixing between platform aragonite, transported from the platform top, and both pelagic and/or diagenetic calcite and dolomite (Swart and Eberli 2005; Higgins et al. 2018). The cores from the bank top (Clino and Unda), record depleted $\delta^{13} \mathrm{C}$ (down to $-7 \%$ ), as a result of meteoric alteration during Plio-Pleistocene glacio-eustatic sea-level fall (Melim et al. 1995). (C) Downcore diagenetic recrystallization of aragonite can be tracked using $\delta^{44 / 40} \mathrm{Ca}$ values (modern seawater as the reference standard) and $\mathrm{Sr} / \mathrm{Ca}$ ratios. Primary platform aragonite sediments have low $\delta^{44 / 40} \mathrm{Ca}$ and high $\mathrm{Sr} / \mathrm{Ca}$ ratios $\left(\mathbf{D}\right.$, high $\left.\delta^{13} \mathrm{C}\right)$, while diagenetic low-Mg calcite or dolomite have high $\delta^{44 / 40} \mathrm{Ca}$ and low $\mathrm{Sr} / \mathrm{Ca}$ ratios (Higgins et al. 2018). 
top (Clino and Unda), adjacent slope (peri-platform), and the basinal environments in the deep waters of the Straight of Florida (Fig. 4A, Eberli et al. 1997; Ginsburg 2001). Chemostratigraphies measured from these cores provide important constraints on the geochemical signatures of platform progradation, oscillating sea-level, and carbonate diagenesis.

Carbonate sediments from the Great Bahama Bank and peri-platform consists of a mixture sourced from the bank top (platform aragonite) and open ocean (pelagic calcifiers) (Eberli et al. 1997; Ginsburg 2001). Stratigraphic variations in the proportion of platform and pelagic carbonate have been linked to changes in eustatic sea-level, with pelagic carbonate dominating during periods of low sea-level and platform-derived carbonate dominating during high sea-level (Swart and Eberli 2005). During sea-level low stands, carbonate platform tops would be exposed, thus shutting down aragonite production and export; conversely, during high stands, the platform is flooded and a highly productive source of aragonite mud (Schlager et al. 1994). The significance of sediment mixing, with respect to carbon isotope chemostratigraphy, is demonstrated by a pronounced correlation between carbonate $\delta^{13} \mathrm{C}$ values and the percentage of aragonite in cores across the Bahamas transect (Swart and Eberli 2005). Aragonite mud, produced by calcareous green algae such as Halimeda on the shallow platform top, has $\delta^{13} \mathrm{C}$ values of $\sim+6 \%$, while pelagic calcite from coccolith and foraminifera tests have values $\sim+1 \%$ (Lowenstam and Epstein 1957; Swart and Eberli 2005). The elevated $\delta^{13} \mathrm{C}$ values of platform aragonite mud are a product of the larger fractionation factor for aragonite compared to calcite, in addition to intense diurnal productivity which elevates the surface water $\delta^{13} \mathrm{C}_{D I C}$ and carbonate saturation in the day time when aragonite precipitates (Swart and Eberli 2005; Geyman and Maloof 2019). As a consequence, shedding of aragonite from the platform during high-stands (Schlager et al. 1994) is recorded by a positive excursion in carbonate $\delta^{13} \mathrm{C}$ values in peri-platform and basinal sediments (Fig. 4). The influence of high-stand aragonite shedding on downslope $\delta^{13} \mathrm{C}$ values is a global phenomenon, owing to the of high-amplitude glacioeustatic sea-level changes in the Plio-Pleistocene (Fig. 4, Swart and Eberli 2005; Swart 2008). This positive 'excursion' is an important example of carbonate $\delta^{13} \mathrm{C}$ values not reflecting global DIC change, despite being broadly correlative across the globe (Swart 2008).

Attributing excursions in $\delta^{13} \mathrm{C}$ values to mixing of aragonite and pelagic calcite is complicated by effects from early marine diagenesis. Geothermal temperature gradients drive the advection of seawater into the platform interior from the slope (Kohout 1965; Henderson et al. 1999), resulting in significant fluid-buffered diagensis of periplatform sediments (Melim et al. 2002; Higgins et al. 2018). These advected fluids initially have $\delta^{13} \mathrm{C}$ values that reflect the open ocean $(\sim+1 \%)$. As a result, fluid-buffered diagenesis of platform derived aragonite results in the resetting of carbon $\delta^{13} \mathrm{C}$ values from +5 to $+1 \%$ (Fig. $4 \mathrm{D}$, Higgins et al. 2018; Ahm et al. 2018). The process is recorded in the slope of the Great Bahamas Bank (Sites 1003 and 1007) as a down-core negative trend in $\delta^{13} \mathrm{C}$ values, caused by the progressive dissolution of metastable platform aragonite and re-precipitation of diagenetically-stable low magnesium calcite or dolomite. Progressive aragonite replacement is also tracked by carbonate $\delta^{44 / 40} \mathrm{Ca}$ values and $\mathrm{Sr} / \mathrm{Ca}$ ratios that correlate with carbonate $\delta^{13} \mathrm{C}$ values in the upper $\sim 150 \mathrm{~m}$ of the periplatform cores (Fig. $4 \mathrm{C})$. Primary platform aragonite has low $\delta^{44 / 40} \mathrm{Ca}$ values $(\sim-1.5 \%$ ) and high $\mathrm{Sr} / \mathrm{Ca}$ ratios $(\sim 10 \mathrm{mmol} / \mathrm{mol})$ due to the higher partition coefficients of $\mathrm{Sr}$ and ${ }^{40} \mathrm{Ca}$ for aragonite than calcite (Tang et al. 2008). During aragonite replacement, $\delta^{44 / 40} \mathrm{Ca}$ is reset to higher values $(\sim-0.5 \%)$ and $\mathrm{Sr} / \mathrm{Ca}$ ratios decrease $(<1 \mathrm{mmol} / \mathrm{mol}$, Higgins et al. 2018).

In addition to invigorating the advection of marine fluids into the platform interior, glacioeustatic sea-level changes in the Plio-Pleistocene resulted in extended periods of platform top exposure (Vahrenkamp et al. 1991; Melim et al. 1995). During glacial maxima, platforms are exposed and the freshwater aquifers within the exposed islands expand, causing meteoric dia- 
genesis of previously deposited aragonite mud (Fig 4, core Clino and Unda). In the meteoric lens, groundwater acquires carbon from the degradation of organic matter in the surrounding sediment, which leads to the release of isotopically light $\mathrm{CO}_{2}$ and the promotion of aragonite dissolution (Allan and Matthews 1977). Due to the influence of respired organic carbon in the freshwater lens, $\delta^{13} \mathrm{C}$ values of re-precipitated low magnesium calcite or dolomite can have very low values, consistent with observations from the Clino and Unda cores (Fig. 4B). During Pleistocene glacial-interglacial transitions, the Bahamas Bank has been exposed repeatedly, leading to a deep profile $(+100 \mathrm{~m})$ of meteoric diagenesis in platform top carbonates (Melim et al. 1995; Swart and Eberli 2005). With regard to carbon isotope chemostratigraphy, widespread synchronous negative excursions in carbonate $\delta^{13} \mathrm{C}$ values are expected as a result of sea-level fall and increase meteoric diagenesis of platform tops (provided significant organic carbon respiration occurs in the fresh water lens). These excursions can be useful stratigraphic markers for correlation, but the $\delta^{13} \mathrm{C}$ would not be tracking perturbations in the global carbon cycle (Allan and Matthews 1977; Dyer et al. 2015; Dyer et al. 2017). The most robust methods to fingerprint negative excursions as meteoric is by comparing other geochemical signatures (e.g., negative $\delta^{13} \mathrm{C}$ correlating with negative $\delta^{18} \mathrm{O}$, or high $\mathrm{Mn}$ concentrations), in addition to petrographic observations of meteoric cements and sedimentological features such as exposure surfaces and root casts.

Owing to the extensive work on carbonate geochemistry from The Bahamas (e.g., Ginsburg 2001; Swart and Eberli 2005; Swart 2008; Oehlert et al. 2012; Oehlert and Swart 2014; Higgins et al. 2018), it is well established that Bahamian carbonate $\delta^{13} \mathrm{C}$ values do not reflect the $\delta^{13} \mathrm{C}_{D I C}$ of a well-mixed ocean in equilibrium with the atmosphere. While carbon isotope chemostratigraphy of pelagic deep-sea sediments may better reflect the global carbon cycle (e.g., Westerhold et al. 2020), the application of chemostratigraphy to ancient platform carbonates is not straight forward. Despite the many complications, in shallow-water pre-Mesozoic sediments across the world there are striking observations of large and broadly coeval stratigraphic excursions in carbonate $\delta^{13} \mathrm{C}$ values (for example: the Permian-Triassic boundary, the Ordovician-Silurian boundary, the Ediacaran Shuram excursion, snowball Earth cap carbonates). Below, we discuss the Neoproterozoic Era, a time period that shows both pronounced variability in $\delta^{13} \mathrm{C}_{\text {carb }}$ values (Fig. 5) and increasing geochronologic evidence for broadly synchronous perturbations $( \pm 5 \mathrm{Myr}$.) in shallow-water carbonate chemistry (Rooney et al. 2020; Swanson-Hysell et al. 2015).

\subsection{The Neoproterozoic}

Due to the lack of index fossils useful for biostratigraphy, carbon isotope chemostratigraphy has been applied widely to correlate Neoproterozoic carbonate successions (1000 - $541 \mathrm{Ma}$, Knoll et al. 1986; Kaufman et al. 1997; Halverson et al. 2005). The variability in $\delta^{13} \mathrm{C}$ values from Neoproterozoic carbonates dwarfs that of the Cenozoic deep sea record (population standard deviation $=4.7 \%$ vs. $0.6 \%$ respectively, Fig. 5 ). The Neoproterozoic record is characterized by high baseline values of $+5-10 \%$ o that are interrupted by dramatic negative excursions with values down to $-15 \%$ (Fig. 5). The origin of the Neoproterozoic carbon isotope excursions is still widely debated, because $\delta^{13} \mathrm{C}$ values below $-5 \%$ can not be explained by a traditional steady state carbon cycle model. Namely, in equation 6 , inserting values for $\delta_{\text {carb }}$ that are below values of $\delta_{\text {riv }}$ will result in a negative number for the fraction of organic carbon buried. As a consequence, several studies have suggested alternative models for generating such negative $\delta^{13} \mathrm{C}$ values, including (1) short-term transient perturbations to the carbon cycle (e.g., Schrag et al. 2002; Rothman et al. 2003; Bjerrum and Canfield 2011), (2) carbonate diagenesis (Derry 2010; Knauth and Kennedy 2009) or (3) the formation of authigenic carbonate minerals (Tziperman et al. 2011; Schrag et al. 2013; Laakso and Schrag 2020). However, these models do not consider the possibility of broadly synchronous shifts in $\delta^{13} \mathrm{C}_{\text {DIC }}$ in platform waters (Swart 2008; Ahm 
et al. 2019; Crockford et al. 2020), that may differ across individual basins on time-scales $>10^{5}$ years, and therefore are unrelated to changes in global DIC - analogous to observations from recent carbonate platforms.

The largest negative carbon isotope excursion in the Neoproterozoic is the Ediacaran ShuramWonoka excursion. This excursion is observed across the globe (e.g., Oman, Australia, Death Valley, Northwest Canada, Siberia) with minima $\delta^{13} \mathrm{C}_{\text {carb }}$ values of $\sim-15 \%$ (Fig. 5). Recent Re-Os ages confirm that the excursion is broadly synchronous, ranging between $\sim 574 \pm 4.7$ to $567 \pm 3.0 \mathrm{Ma}$ (Rooney et al. 2020). These broad geochronological constraints, however, do not necessarily require that the excursion represent a global carbon cycle perturbation (sensu Fig. 2). Similarly to observations from recent platform carbonate, $\delta^{44 / 40} \mathrm{Ca}$ data from the Wonoka Formation (South Australia) suggests that much of the carbonate that make up the anomaly was aragonite, originally formed in platformal settings, transported down slope, and recrystallized to low-Mg calcite during sediment-buffered diagenesis (Husson et al. 2015). Large systematic changes in $\delta^{44 / 40} \mathrm{Ca}$ values (between -0.5 to $-2.0 \%$ ) occur across the excursion (Fig. 5B,C), which is inconsistent with changes in the global calcium cycle and indicate that these sediments cannot represent the average carbonate burial sink (on timescale $>10^{6}$ yrs, Blättler and Higgins 2017). Moreover, in-situ measurements of $\delta^{13} \mathrm{C}$ values via secondary ion mass spectrometry on individual carbonate grains, representing both authigenic phases and transported platform sediments, yielded a large range (from +5 to $-15 \%$ ) from a single hand sample (Husson et al. 2020). These results suggest that the carbonates recording the Shuram excursion are recording a specific Ediacaran surface environment and not changes in the $\delta^{13} \mathrm{C}_{D I C}$ of average seawater. The Shuram excursion may therefore be a broadly synchronous chemostratigraphic marker that track changes to global climate, tectonics, or sea-level over millions of years (Rooney et al. 2020), without tracking global $\delta^{13} \mathrm{C}_{D I C}$.

Similar to the Shuram excursion, correlated changes in both carbonate $\delta^{13} \mathrm{C}$ and $\delta^{44 / 40} \mathrm{Ca}$ values are found in the globally distributed, basal Ediacaran carbonates ( $635 \mathrm{Ma})$ that "cap" glacial deposits created during the pan-glacial "Snowball Earth" climate state (Hoffman et al. 2017). In these cap carbonates, $\delta^{13} \mathrm{C}$ values in limestones reach $-6 \%$, coinciding with low $\delta^{44 / 40} \mathrm{Ca}$ values $(-2 \%$ o $)$ and high $\mathrm{Sr} / \mathrm{Ca}$ ratios $(\sim 4 \mathrm{mmol} / \mathrm{mol})$, consistent with signatures of sediment-buffered recrystallization of platform aragonite (Ahm et al. 2019). In contrast, dolostone portions of the cap sequence have higher $\delta^{13} \mathrm{C}$ and $\delta^{44 / 40} \mathrm{Ca}$ values, approaching values of modern seawater, suggesting that fluid-buffered dolomitization in reaction with Ediacaran seawater was responsible for resetting the primary low $\delta^{13} \mathrm{C}$ values. These results indicate that the surface waters of platforms, where aragonite was forming, were significantly depleted in ${ }^{13} \mathrm{C}(-6 \%$ ), while the open ocean had $\delta^{13} \mathrm{C}_{D I C}$ values close to $0 \%$. Multiple cap carbonate sections measured across individual basins reveal systematic spatial gradients in both $\delta^{13} \mathrm{C}$ and $\delta^{44 / 40} \mathrm{Ca}$ that are related to original basin geometry. The lowest values in both isotopic systems, representing sedimentbuffered diagenesis, are found in sections from the platform interior, while the highest values, representing fluid-buffered diagenesis, are characteristic of the platform edge and upper slope (Ahm et al. 2019). These spatial trends are consistent with patterns of geothermal convection of fluids through recent platforms (Kohout 1965; Henderson et al. 1999), where warm, buoyantly riding fluid in the platform interior leads to compensatory flow of cold seawater into the sediment pile from the platform slope. An implication of these observations is that $\delta^{13} \mathrm{C}$ values of dolostone, formed via fluid-buffered diagenesis with seawater, may be more reliable recorders of average seawater in comparison to shallow-water carbonate from the platform interior (Ahm et al. 2019; Hoffman and Lamothe 2019).

The results from the cap carbonates adds to the growing body of evidence that Neoproterozoic shallow water environments were characterized by large fluctuations in $\delta^{13} \mathrm{C}$ values, decoupled 

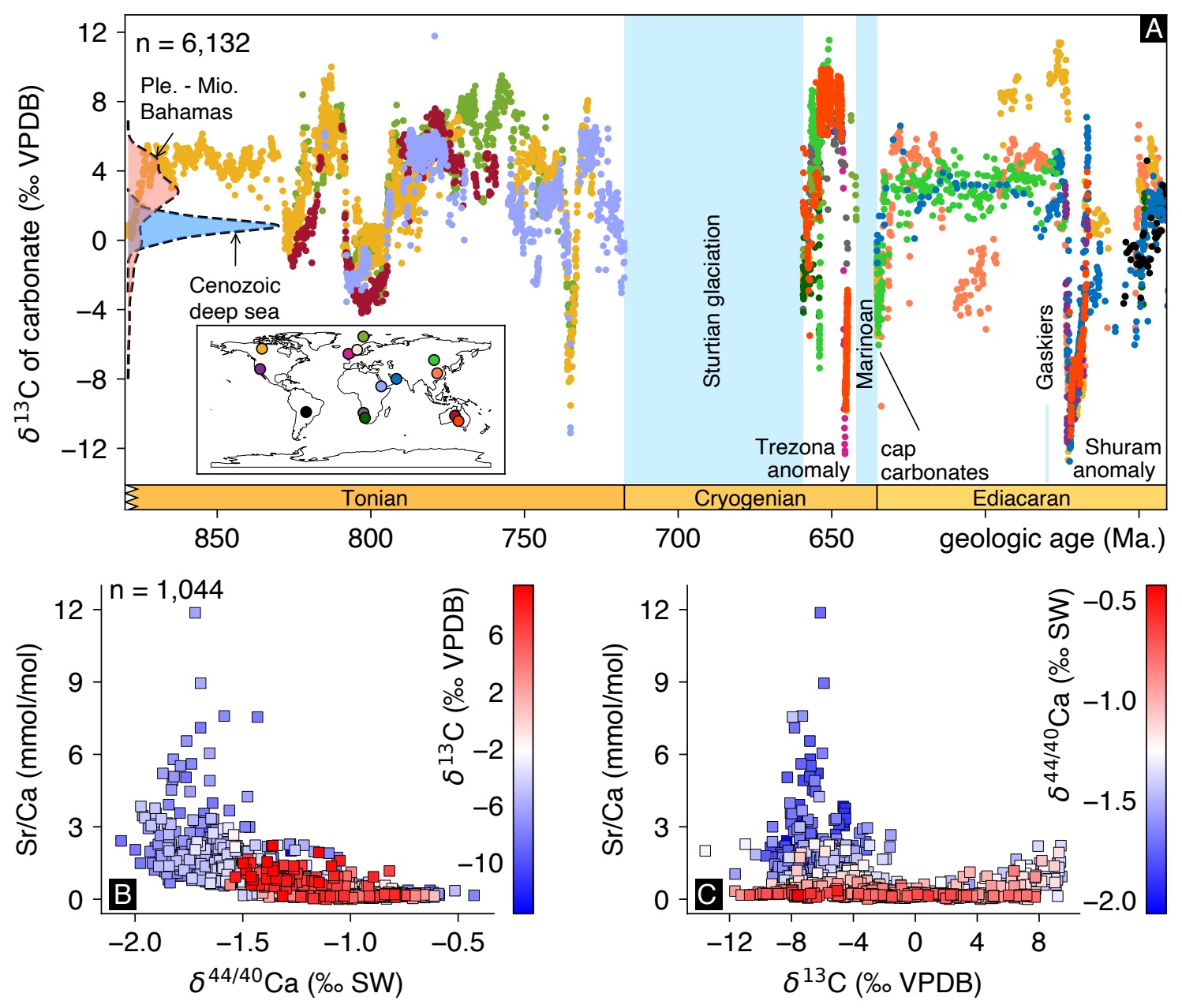

Figure 5: (A) A global compilation of $\delta^{13} \mathrm{C}$ values from Neoproterozoic carbonates. The Tonian and Ediacaran age models are derived from Swanson-Hysell et al. (2015) and Rooney et al. (2020), with age constraints for the Cryogenian from Hoffman et al. (2017). Data points are color-coded to approximate geographic locality shown in the inset map. Kernel density estimates of distributions of $\delta^{13} \mathrm{C}$ values from both the Bahamas (red, Pleistocene-Miocene in age; Swart and Eberli 2005; Melim et al. 1995) and deep sea sediment cores (blue, Cenozoic in age, Westerhold et al. 2020) are also shown. The height of each density estimate is arbitrary. (B,C) Cross-plots of $\delta^{44 / 40} \mathrm{Ca}, \delta^{13} \mathrm{C}$ and $\mathrm{Sr} / \mathrm{Ca}$ values from carbonates with notable excursions in carbon isotopes: the Trezona and Shuram anomalies (Ahm et al. in review; Husson et al. 2015), and basal Ediacaran cap carbonates (Ahm et al. 2019).

from the average ocean value (Bold et al. 2020; Crockford et al. 2020). Various mechanisms have been proposed to explain the origin of very depleted $\delta^{13} \mathrm{C}$ values in Neoproterozoic platform interior carbonates but, as of yet, no single hypothesis is accepted widely. Potentially important processes include nucleation kinetics associated with non-skeletal carbonate production (Hoffman and Lamothe 2019), the influence of microbial mats on the precipitation of carbonate, and the rapid invasion of $\mathrm{CO}_{2}$ during periods of intense productivity (Lazar and Erez 1992). Whether or not these mechanisms could create broadly synchronous $\delta^{13} \mathrm{C}$ excursions in shallowwater carbonates globally, and what boundary conditions are necessary for such synchronous changes, is an important avenue of ongoing research in Earth history. 


\section{$5 \quad$ Future prospects}

The original framework of carbon isotope chemostratigraphy built on the assumption that $\delta^{13} \mathrm{C}_{c a r b}$ values directly record the $\delta^{13} \mathrm{C}_{D I C}$ values of average seawater, in a well-mixed ocean in equilibrium with the atmosphere (e.g., Broecker 1970; Kump and Arthur 1999). Research though the last 20 years, however, has documented the importance of considering local variability in $\delta^{13} \mathrm{C}_{\text {carb }}$ in platform environments (e.g., Holmden et al. 1998; Swart and Eberli 2005; Oehlert and Swart 2014). These findings have demonstrated that carbon isotope chemostratigraphy from shallow-water strata rarely records changes in global $\delta^{13} \mathrm{C}_{D I C}$ or the relative burial flux of organic carbon, $f_{\text {org }}$.

It is likely that stratigraphic changes in $\delta^{13} \mathrm{C}_{\text {carb }}$ broadly correlate both within basins and across continents, driven by external forcings such as global climate change, tectonics, and sea-level. To a first order, carbon isotope chemostratigraphy has provided robust correlation tie-points, with uncertainties from hundred thousand to millions of years (Rooney et al. 2020; SwansonHysell et al. 2015) - similarly to the time constraints provided by biostratigraphy applied in shallow-water environments (Holland 2020). Importantly, these uncertainties should be considered when making arguments related to the global carbon cycle, which requires time constraints on scales of $<10^{5}$ years in order to estimate average carbon burial fluxes.

Going forward, to help constrain globally-averaged carbonate burial on time-scales $>10^{6}$ years, measurements of carbonate $\delta^{44 / 40} \mathrm{Ca}$ values from thick carbonate successions can be a powerful approach (Blättler and Higgins 2017; Higgins et al. 2018). Modeling studies of carbonate diagenesis that combine measurements of $\delta^{13} \mathrm{C}, \delta^{44 / 40} \mathrm{Ca}$, and $\mathrm{Sr} / \mathrm{Ca}$ ratios, have demonstrated that by embracing the diagenetic history of ancient carbonate it is possible to derived more accurate records of seawater chemistry (Ahm et al. 2018). Specifically, carbonate successions that have experienced early marine diagenesis and/or dolomitization may be important, and yet-to-be explored, archives of ancient seawater chemistry (Ahm et al. 2019; Hoffman and Lamothe 2019; Crockford et al. 2020). Finally, by accepting that shallow-water sedimentary records largely reflect local carbon cycle dynamics, we may find that $\delta^{13} \mathrm{C}$ measurements instead reflect the local fingerprints of important climatic and evolutionary processes.

\section{Designated key papers}

The references below are a selected list (ordered by year of publication) of the 'classics' and 'best of the new' that specifically evaluate the implications of diagenesis and local controls on carbon isotope chemostratigraphy:

- Allan, J.R., Matthews, R.K., 1977. Carbon and oxygen isotopes as diagenetic and stratigraphic tools: Surface and subsurface data, Barbados, West Indies. Geology 5 (1), 16-20. One of the first studies to show the impacts of diagenesis on carbon isotope chemostratigraphy

- Banner, J.L., Hanson, G.N., 1990. Calculation of simultaneous isotopic and trace element variations during water-rock interaction with applications to carbonate diagenesis. Geochimica et Cosmochomica Acta 54 (11), 3123-3137. Fundamental study that demonstrates the sensitivity of carbonate $\delta^{13} \mathrm{C}$ values to alteration using a fluid-rock interaction model.

- Patterson, W.P., Walter, L.M., 1994. Depletion of ${ }^{13} \mathrm{C}$ in seawater $\mathrm{CO}_{2}$ on modern carbonate platforms: Significance for the carbon isotopic record of carbonates. Geology 22, 885-888. One of the first studies to show significant isotopic variation of modern bank top waters, due to the respiration of marine and terrestrial organic matter. 
- Holmden, C., Creaser, R.A., Muehlenbacks, K., Leslie, S.A., Bergström, S.M. et al. 1998. Isotopic evidence for geochemical decoupling between ancient epeiric seas and bordering oceans: Implications for secular curves. Geology 26 (6), 567-570. One of the first studies to discuss the implications of local variations in geochemical aquafacies on secular carbon isotope trends in ancient platforms.

- Swart, P.K., Eberli, G., 2005. The nature of the $\delta^{13} \mathrm{C}$ of periplatform sediments: Implications for stratigraphy and the global carbon cycle. Sedimentary Geology 175 (1-4), 115-129. Study that contextualizes the findings of the Bahamas drilling project and ODP Leg 166, and discuss the implications for carbon isotope chemostratigraphy.

- Oehlert, A.M. Swart, P.K., 2014. Interpreting carbonate and organic carbon isotope covariance in the sedimentary record. Nature Communications 5 (1), 4672. This study compares the variability of organic and carbonate $\delta^{13} C$ values from platform settings and find that covariation can result from mixing and sediment transport.

- Higgins, J.A., Blättler, C.L., Lundstrom, E.A., Santiago-Ramos, D.P., Akhtar, A.A., Ahm, A-S.C., Bialik, O., Holmden, C., Bradbury, H., Murray, S.T., Swart. P.K., 2018. Mineralogy, early marine diagenesis, and the chemistry of shallow-water carbonate sediments. Geochimica et Cosmochimica Acta 220, 512-534. This study demonstrates that early-marine diagenesis has large impact on geochemical records of $\delta^{44} \mathrm{Ca}$ and $\delta^{13} \mathrm{C}$ from platform settings.

- Hoffman, P.F., and Lamothe, K.G., 2019. Seawater-buffered diagenesis, destruction of carbon isotope excursions, and the composition of DIC in Neoproterozoic oceans. PNAS 116 (38), 18874-18879. This study finds that large spatial gradients in $\delta^{13} C$ exist across Neoproterozoic carbonate platforms as a result of early marine diagenesis.

- Geyman, E.C., and Maloof, A.M., 2019. A diurnal carbon engine explains 13C-enriched carbonates without increasing the global production of oxygen. PNAS 116 (49), 2443324439. This study demonstrates that highly ${ }^{13} \mathrm{C}$-enriched carbonate can be produced in platform environments without increasing the local or global burial flux of organic carbon.

\section{References}

Ahm, Anne-Sofie C, Bjerrum, Christian J, Blättler, Clara L, Swart, Peter K, and Higgins, John A (2018). "Quantifying early marine diagenesis in shallow-water carbonate sediments". In: Geochimica et Cosmochimica Acta 236, pp. 140-159. DOI: 10.1016/j.gca.2018.02.042.

Ahm, Anne-Sofie C, Maloof, Adam C, Macdonald, Francis A, Hoffman, Paul F, Bjerrum, Christian J, Bold, Uyanga, Rose, Catherine V, Strauss, Justin V, and Higgins, John A (2019). "An early diagenetic deglacial origin for basal Ediacaran "cap dolostones"". In: Earth and Planetary Science Letters 506, pp. 292-307. DOI: 10.1016/j.epsl.2018.10.046.

Allan, JR and Matthews, RK (1977). "Carbon and oxygen isotopes as diagenetic and stratigraphic tools: surface and subsurface data, Barbados, West Indies". In: Geology 5.1, pp. 1620. DOI: $10.1130 / 0091-7613(1977) 5<16:$ CAOIAD $>2.0$. CO 2 .

Banner, Jay L and Hanson, Gilbert N (1990). "Calculation of simultaneous isotopic and trace element variations during water-rock interaction with applications to carbonate diagenesis". In: Geochimica et Cosmochimica Acta 54.11, pp. 3123-3137.

Beeler, Scott R., Gomez, Fernando J., and Bradley, Alexander S. (2020). "Controls of extreme isotopic enrichment in modern microbialites and associated abiogenic carbonates". In: Geochimica et Cosmochimica Acta 269, pp. 136-149. DOI: 10.1016/j.gca.2019.10.022. Berner, Robert A (2006). "GEOCARBSULF: a combined model for Phanerozoic atmospheric $\mathrm{O}_{2}$ and $\mathrm{CO}_{2}$ ". In: Geochimica et Cosmochimica Acta 70.23, pp. 5653-5664. DOI: 10.1016/j . gca.2005.11.032. 
Birgel, D., Meister, P., Lundberg, R., Horath, T. D., Bontognali, T. R. R., Bahniuk, A. M., Rezende, C. E. de, Vasconcelos, C., and McKenzie, J. A. (2015). "Methanogenesis produces strong ${ }^{13} \mathrm{C}$ enrichment in stromatolites of Lagoa Salgada, Brazil: a modern analogue for Palaeo-/Neoproterozoic stromatolites?" In: Geobiology 13.3, pp. 245-266. DOI: 10 . 1111 / gbi.12130.

Bjerrum, Christian J and Canfield, Donald E (2004). "New insights into the burial history of organic carbon on the early Earth". In: Geochemistry, Geophysics, Geosystems 5.8.

- (2011). "Towards a quantitative understanding of the late Neoproterozoic carbon cycle". In: Proceedings of the National Academy of Sciences 108.14, p. 5542. DOI: $10.1073 /$ pnas . 1101755108.

Blättler, Clara L and Higgins, John A (2017). "Testing Urey's carbonate-silicate cycle using the calcium isotopic composition of sedimentary carbonates". In: Earth and Planetary Science Letters 479, pp. 241-251. DOI: 10.1016/j.epsl.2017.09.033.

Bold, Uyanga, Ahm, Anne-Sofie C, Schrag, Daniel P, Higgins, John A, Jamsran, Erdenebayar, and Macdonald, Francis A (2020). "Effect of dolomitization on isotopic records from Neoproterozoic carbonates in southwestern Mongolia". In: Precambrian Research 350, p. 105902. DOI: $10.1016 / \mathrm{j}$. precamres .2020.105902.

Bown, Paul R., Lees, Jackie A., and Young, Jeremy R. (2004). "Calcareous nannoplankton evolution and diversity through time". In: ed. by Hans R. Thierstein and Jeremy R. Young. Berlin, Heidelberg: Springer Berlin Heidelberg, pp. 481-508. DOI: 10 . 1007 /978-3-66206278-4_18.

Broecker, Wallace S (1970). "A boundary condition on the evolution of atmospheric oxygen". In: Journal of Geophysical Research 75.18, pp. 3553-3557. DOI: 10.1029/JC075i018p03553.

Campeau, Audrey, Wallin, Marcus B, Giesler, Reiner, Löfgren, Stefan, Mörth, Carl-Magnus, Schiff, Sherry, Venkiteswaran, Jason J, and Bishop, Kevin (2017). "Multiple sources and sinks of dissolved inorganic carbon across Swedish streams, refocusing the lens of stable C isotopes". In: Scientific Reports 7.1, pp. 1-14. DOI: 10.1038/s41598-017-09049-9.

Canfield, Donald E., Knoll, Andrew H., Poulton, Simon W., Narbonne, Guy M., and Dunning, Gregory R. (2020). "Carbon isotopes in clastic rocks and the Neoproterozoic carbon cycle". In: American Journal of Science 320.2, pp. 97-124. DOI: 10.2475/02.2020.01.

Clark, Ian D., Fontes, Jean-Charles, and Fritz, Peter (1992). "Stable isotope disequilibria in travertine from high $\mathrm{pH}$ waters: Laboratory investigations and field observations from Oman". In: Geochimica et Cosmochimica Acta 56.5, pp. 2041-2050. DOI: 10.1016/0016-7037(92) 90328-G.

Claypool, George E. and Kaplan, I. R. (1974). "The Origin and Distribution of Methane in Marine Sediments". In: Natural Gases in Marine Sediments. Ed. by Isaac R. Kaplan. Springer US, pp. 99-139. DOI: 10.1007/978-1-4684-2757-8_8.

Craig, Harmon (1953). "The geochemistry of the stable carbon isotopes". In: Geochimica et Cosmochimica Acta 3.2-3, pp. 53-92. DOI: 10.1016/0016-7037(53)90001-5.

Crockford, Peter W, Kunzmann, Marcus, Blättler, Clara L, Kalderon-Asael, Boriana, Murphy, Jack G, Ahm, Anne-Sofie C, Sharoni, Shlomit, Halverson, Galen P, Planavsky, Noah J, Halevy, Itay, and Higgins, John A (2020). "Reconstructing Neoproterozoic seawater chemistry from early diagenetic dolomite". In: Geology. DOI: 10.1130/G48213.1.

Derry, Louis A (2010). "A burial diagenesis origin for the Ediacaran Shuram-Wonoka carbon isotope anomaly". In: Earth and Planetary Science Letters 294.1-2, pp. 152-162. DOI: 10. 1016/j.epsl.2010.03.022.

Dyer, Blake, Higgins, John A, and Maloof, Adam C (2017). "A probabilistic analysis of meteorically altered $\delta^{1} 3 \mathrm{C}$ chemostratigraphy from late Paleozoic ice age carbonate platforms". In: Geology 45.2, pp. 135-138. DOI: 10.1130/G38513.1. 
Dyer, Blake, Maloof, Adam C, and Higgins, John A (2015). "Glacioeustasy, meteoric diagenesis, and the carbon cycle during the Middle Carboniferous". In: Geochemistry, Geophysics, Geosystems 16.10, pp. 3383-3399. DOI: 10.1002/2015GC006002.

Eberli, Gregor P, Swart, PK, McNeill, DF, Kenter, JAM, Anselmetti, FS, Melim, LA, and Ginsburg, RN (1997). "A synopsis of the Bahamas Drilling Project: results from two deep core borings drilled on the Great Bahama Bank". In: Proceedings of the ocean drilling program, initial reports. Vol. 166, pp. 23-41. DOI: 10.2973/odp.proc.ir.166.1997.

Fantle, M. S., Maher, K. M., and DePaolo, D. J. (2010). "Isotopic approaches for quantifying the rates of marine burial diagenesis". In: Reviews of Geophysics 48.3. DoI: https://doi. org/10.1029/2009RG000306.

Fantle, Matthew S. and DePaolo, Donald J. (2007). "Ca isotopes in carbonate sediment and pore fluid from ODP Site 807A: The $\mathrm{Ca}^{2}+(\mathrm{aq})$-calcite equilibrium fractionation factor and calcite recrystallization rates in Pleistocene sediments". In: Geochimica et Cosmochimica Acta 71.10, pp. 2524-2546. DOI: $10.1016 /$ j.gca.2007.03.006.

Fantle, Matthew S. and Higgins, John (2014). "The effects of diagenesis and dolomitization on $\mathrm{Ca}$ and $\mathrm{Mg}$ isotopes in marine platform carbonates: Implications for the geochemical cycles of Ca and Mg". In: Geochimica et Cosmochimica Acta 142, pp. 458-481. DOI: 10.1016/j . gca.2014.07.025.

Geyman, Emily C and Maloof, Adam C (2019). "A diurnal carbon engine explains ${ }^{13} \mathrm{C}$-enriched carbonates without increasing the global production of oxygen". In: Proceedings of the $\mathrm{Na}$ tional Academy of Sciences 116.49, pp. 24433-24439. DOI: 10.1073/pnas. 1908783116.

Ginsburg, Robert N (2001). "The Bahamas drilling project: background and acquisition of cores and logs". In: DOI: 10.2110/pec.01.70.0003.

Gregor, B (1970). "Denudation of the continents". In: Nature 228.5268, pp. 273-275. DOI: 10. 1038/228273a0.

Gussone, Nikolaus, Ahm, Anne-Sofie C, Lau, Kimberly V, and Bradbury, Harold J (2020). "Calcium isotopes in deep time: Potential and limitations". In: Chemical Geology, p. 119601. Gussone, Nikolaus, Böhm, Florian, Eisenhauer, Anton, Dietzel, Martin, Heuser, Alexander, Teichert, Barbara M. A., Reitner, Joachim, Wörheide, Gert, and Dullo, Wolf-Christian (2005). "Calcium isotope fractionation in calcite and aragonite". In: Geochimica et Cosmochimica Acta 69.18, pp. 4485-4494. DOI: 10.1016/j.gca.2005.06.003.

Halverson, Galen P, Hoffman, Paul F, Schrag, Daniel P, Maloof, Adam C, and Rice, A Hugh N (2005). "Toward a Neoproterozoic composite carbon-isotope record". In: GSA bulletin 117.910, pp. 1181-1207. DOI: 10.1130/B25630.1.

Harper, Brandon B., Puga-Bernabéu, Ángel, Droxler, André W, Webster, Jody M., Gischler, Eberhard, Tiwari, Manish, Lado-Insua, Tania, Thomas, Alex L., Morgan, Sally, Jovane, Luigi, and Röhl, Ursula (2015). "Mixed Carbonate-Siliciclastic Sedimentation Along the Great Barrier Reef Upper Slope: A Challenge To the Reciprocal Sedimentation Model". In: Journal of Sedimentary Research 85.9, pp. 1019-1036. DOI: 10.2110/jsr.2015.58.1.

Hayes, John M., Strauss, Harald, and Kaufman, Alan J. (1999). "The abundance of ${ }^{13} \mathrm{C}$ in marine organic matter and isotopic fractionation in the global biogeochemical cycle of carbon during the past 800 Ma". In: Chemical Geology 161.1, pp. 103-125. DOI: 10.1016/S00092541 (99) 00083-2.

Henderson, Gideon M, Slowey, Niall C, and Haddad, Geoff A (1999). "Fluid flow through carbonate platforms: Constraints from ${ }^{234} \mathrm{U} /{ }^{238} \mathrm{U}$ and $\mathrm{Cl}^{-}$in Bahamas pore-waters". In: Earth and Planetary Science Letters 169.1-2, pp. 99-111. DOI: 10.1016/S0012-821X(99)00065-5.

Higgins, J.A., Fischer, W.W., and Schrag, D.P. (2009). "Oxygenation of the ocean and sediments: Consequences for the seafloor carbonate factory". In: Earth and Planetary Science Letters 284.1-2, pp. 25-33. DOI: 10.1016/j.epsl.2009.03.039.

Higgins, John A, Blättler, Clara L, Lundstrom, EA, Santiago-Ramos, DP, Akhtar, AA, Ahm, Anne-Sofie C, Bialik, O, Holmden, Chris, Bradbury, H, Murray, ST, et al. (2018). "Mineral- 
ogy, early marine diagenesis, and the chemistry of shallow-water carbonate sediments". In: Geochimica et Cosmochimica Acta 220, pp. 512-534. DOI: 10.1016/j.gca.2017.09.046.

Hoffman, Paul F, Abbot, Dorian S, Ashkenazy, Yosef, Benn, Douglas I, Brocks, Jochen J, Cohen, Phoebe A, Cox, Grant M, Creveling, Jessica R, Donnadieu, Yannick, Erwin, Douglas H, et al. (2017). "Snowball Earth climate dynamics and Cryogenian geology-geobiology". In: Science Advances 3.11, e1600983. DOI: 10.1126/sciadv.1600983.

Hoffman, Paul F and Lamothe, Kelsey G (2019). "Seawater-buffered diagenesis, destruction of carbon isotope excursions, and the composition of DIC in Neoproterozoic oceans". In: Proceedings of the National Academy of Sciences 116, pp. 18874-18879. DOI: 10.1073/pnas . 1909570116.

Holland, Steven M. (2020). "The Stratigraphy of Mass Extinctions and Recoveries". In: Annual Review of Earth and Planetary Sciences 48.1, pp. 75-97. DOI: $10.1146 /$ annurev-earth071719-054827.

Holmden, C., Panchuk, K., and Finney, S.C. (2012). "Tightly coupled records of Ca and C isotope changes during the Hirnantian glaciation event in an epeiric sea setting". In: Geochimica et Cosmochimica Acta 98, pp. 94-106. DOI: 10.1016/j.gca.2012.09.017.

Holmden, Chris, Creaser, RA, Muehlenbachs, KLSA, Leslie, SA, and Bergstrom, SM (1998). "Isotopic evidence for geochemical decoupling between ancient epeiric seas and bordering oceans: implications for secular curves". In: Geology 26.6, pp. 567-570. DOI: 10.1130/00917613(1998) 026<0567: IEFGDB>2 . 3. C0; 2.

Hovland, Martin, Talbot, Michael R., Qvale, Henning, Olaussen, Snorre, and Aasberg, Lars (1987). "Methane-related carbonate cements in pockmarks of the North Sea". In: Journal of Sedimentary Research 57.5, pp. 881-892. DOI: 10 . 1306/212F8C92-2B24-11D78648000102C1865D.

Husson, Jon M, Higgins, John A, Maloof, Adam C, and Schoene, Blair (2015). "Ca and Mg isotope constraints on the origin of Earth's deepest $\delta^{13} \mathrm{C}$ excursion". In: Geochimica et Cosmochimica Acta 160, pp. 243-266. DOI: 10.1016/j.gca.2015.03.012.

Husson, Jon M, Linzmeier, Benjamin J, Kitajima, Kouki, Ishida, Akizumi, Maloof, Adam C, Schoene, Blair, Peters, Shanan E, and Valley, John W (2020). "Large isotopic variability at the micron-scale in 'Shuram' excursion carbonates from South Australia". In: Earth and Planetary Science Letters 538, p. 116211. DOI: 10.1016/j.epsl.2020.116211.

Jacobson, Andrew D. and Holmden, Chris (2008). " $\delta{ }^{44} \mathrm{Ca}$ evolution in a carbonate aquifer and its bearing on the equilibrium isotope fractionation factor for calcite". In: Earth and Planetary Science Letters 270.3, pp. 349-353. DOI: 10.1016/j.eps1.2008.03.039.

Kaufman, A. J., Knoll, A. H., and Narbonne, G. M. (1997). "Isotopes, ice ages, and terminal Proterozoic earth history". In: Proceedings of the National Academy of Sciences 94.13, pp. 6600-6605. DOI: 10.1073/pnas.94.13.6600.

Keigwin, LD and Shackleton, NJ (1980). "Uppermost Miocene carbon isotope stratigraphy of a piston core in the equatorial Pacific". In: Nature 284.5757, pp. 613-614. DOI: 10.1038/ $284613 \mathrm{a} 0$.

Keith, ML and Weber, JN (1964). "Carbon and oxygen isotopic composition of selected limestones and fossils". In: Geochimica et cosmochimica acta 28.10-11, pp. 1787-1816. DOI: 10 . 1016/0016-7037 (64)90022-5.

Khadka, Mitra B., Martin, Jonathan B., and Jin, Jin (2014). "Transport of dissolved carbon and $\mathrm{CO}_{2}$ degassing from a river system in a mixed silicate and carbonate catchment". In: Journal of Hydrology 513, pp. 391-402. DOI: 10.1016/j . jhydrol.2014.03.070.

King, Arthur S and Birge, Raymond T (1929). "An isotope of carbon, mass 13". In: Nature 124.3117, pp. 127-127.

Knauth, L. Paul and Kennedy, Martin J. (2009). "The late Precambrian greening of the Earth". In: Nature 460.7256 , pp. $728-732$. DOI: $10.1038 /$ nature08213. 
Knoll, A.H., Hayes, J.M., Kaufman, A.J., Swett, K., and Lambert, I.B. (1986). "Secular variation in carbon isotope ratios from Upper Proterozoic successions of Svalbard and East Greenland". In: Nature 321.6073, pp. 832-838. DOI: 10.1038/321832a0.

Kohout, F.A. (1965). "A hypothesis concerning cyclic flow of salt water related to geothermal heating in the Floridan aquifer". In: New York Academy of Sciences Transactions 28, pp. 249271. DOI: $10.1111 / \mathrm{j} .2164-0947.1965 . \mathrm{tb02879} . \mathrm{x}$.

Komar, N. and Zeebe, R. E. (2016). "Calcium and calcium isotope changes during carbon cycle perturbations at the end-Permian: END-PERMIAN CALCIUM CYCLE". In: Paleoceanography 31.1, pp. 115-130. DOI: 10.1002/2015PA002834.

Kump, L. R, Arthur, M. A, Patzkowsky, M. E, Gibbs, M. T, Pinkus, D. S, and Sheehan, P. M (1999). "A weathering hypothesis for glaciation at high atmospheric $\mathrm{pCO}_{2}$ during the Late Ordovician". In: Palaeogeography, Palaeoclimatology, Palaeoecology 152.1, pp. 173-187. DOI: 10.1016/S0031-0182(99)00046-2.

Kump, Lee R and Arthur, Michael A (1999). "Interpreting carbon-isotope excursions: carbonates and organic matter". In: Chemical Geology 161.1-3, pp. 181-198. DOI: 10.1016/S00092541 (99) 00086-8.

Laakso, Thomas A and Schrag, Daniel P (2020). "The role of authigenic carbonate in Neoproterozoic carbon isotope excursions". In: Earth and Planetary Science Letters 549, p. 116534. DOI: $10.1016 / j . e p s l .2020 .116534$.

Lazar, Boaz and Erez, Jonathan (1992). "Carbon geochemistry of marine-derived brines: I. $\delta^{13} \mathrm{C}$ depletions due to intense photosynthesis". In: Geochimica et Cosmochimica Acta 56.1, pp. 335-345. DOI: 10.1016/0016-7037 (92) 90137-8.

Loutit, Tom S and Kennett, James P (1979). "Application of carbon isotope stratigraphy to late Miocene shallow marine sediments, New Zealand". In: Science 204.4398, pp. 1196-1199. DOI: $10.1126 /$ science.204.4398.1196.

Lowenstam, Heinz A and Epstein, Samuel (1957). "On the origin of sedimentary aragonite needles of the Great Bahama Bank". In: The Journal of Geology 65.4, pp. 364-375. DOI: $10.1086 / 626439$.

Lynch-Stieglitz, Jean, Stocker, Thomas F, Broecker, Wallace S, and Fairbanks, Richard G (1995). "The influence of air-sea exchange on the isotopic composition of oceanic carbon: Observations and modeling". In: Global Biogeochemical Cycles 9.4, pp. 653-665. DOI: 10 . 1029/95GB02574.

Maher, D. T., Santos, I. R., Golsby-Smith, L., Gleeson, J., and Eyre, B. D. (2013). "Groundwaterderived dissolved inorganic and organic carbon exports from a mangrove tidal creek: The missing mangrove carbon sink?" In: Limnology and Oceanography 58.2, pp. 475-488. DOI: $10.4319 / 10.2013 .58 \cdot 2.0475$.

Melim, L. A, Westphal, H, Swart, P. K, Eberli, G. P, and Munnecke, A (2002). "Questioning carbonate diagenetic paradigms: evidence from the Neogene of the Bahamas". In: Marine Geology 185.1, pp. 27-53. DOI: 10.1016/S0025-3227(01)00289-4.

Melim, Leslie A, Swart, Peter K, and Maliva, Robert G (1995). "Meteoric-like fabrics forming in marine waters: Implications for the use of petrography to identify diagenetic environments". In: Geology, p. 4. DOI: 10.1130/0091-7613(1995) 023<0755:MLFFIM>2.3. C0; 2.

Murray, Sean T., Higgins, John A., Holmden, Chris, Lu, Chaojin, and Swart, Peter K. (2021). "Geochemical fingerprints of dolomitization in Bahamian carbonates: Evidence from sulphur, calcium, magnesium and clumped isotopes". In: Sedimentology 68.1, pp. 1-29. DoI: doi.org/ 10.1111/sed. 12775 .

Nier, Alfred O and Gulbransen, Earl A (1939). "Variations in the relative abundance of the carbon isotopes". In: Journal of the American Chemical Society 61.3, pp. 697-698. DoI: doi . org/10.1021/ja01872a047.

Oehlert, Amanda M, Lamb-Wozniak, Kathryn A, Devlin, Quinn B, Mackenzie, Greta J, Reijmer, John JG, and Swart, Peter K (2012). "The stable carbon isotopic composition of organic 
material in platform derived sediments: implications for reconstructing the global carbon cycle". In: Sedimentology 59.1, pp. 319-335. DOI: 10.1111/j.1365-3091.2011.01273.x.

Oehlert, Amanda M and Swart, Peter K (2014). "Interpreting carbonate and organic carbon isotope covariance in the sedimentary record". In: Nature Communications 5.1, pp. 1-7. DOI: $10.1038 /$ ncomms 5672 .

Opdyke, Bradley N. and Wilkinson, Bruce H. (1988). "Surface area control of shallow cratonic to deep marine carbonate accumulation". In: Paleoceanography 3.6, pp. 685-703. DOI: doi . org/10.1029/PA003i006p00685.

Patterson, William $\mathrm{P}$ and Walter, Lynn $\mathrm{M}$ (1994). "Depletion of ${ }^{13} \mathrm{C}$ in seawater $\mathrm{\Sigma CO}_{2}$ on modern carbonate platforms: Significance for the carbon isotopic record of carbonates". In: Geology 22.10, pp. 885-888. DOI: 10.1130/0091-7613(1994) 022<0885:DOCISC>2.3.CO; 2.

Pearson, A (2010). "Pathways of carbon assimilation and their impact on organic matter values $\delta^{13}$ C". In: Handbook of Hydrocarbon and Lipid Microbiology. DOI: 10 . 1007/978-3-54077587-4_9.

Popp, Brian N, Laws, Edward A, Bidigare, Robert R, Dore, John E, Hanson, Kristi L, and Wakeham, Stuart G (1998). "Effect of phytoplankton cell geometry on carbon isotopic fractionation". In: Geochimica et cosmochimica acta 62.1, pp. 69-77. DOI: 10 .1016/S0016$7037(97) 00333-5$.

Richardson, Christina M., Dulai, Henrietta, Popp, Brian N., Ruttenberg, Kathleen, and Fackrell, Joseph K. (2017). "Submarine groundwater discharge drives biogeochemistry in two Hawaiian reefs". In: Limnology and Oceanography 62.S1, S348-S363. DOI: doi .org/10 . 1002/Ino . 10654.

Rodriguez Blanco, Leticia, Eberli, Gregor P., Weger, Ralf J., Swart, Peter K., Tenaglia, Maximillian, Rueda Sanchez, Laura E., and McNeill, Donald F. (2020). "Periplatform ooze in a mixed siliciclastic-carbonate system - Vaca Muerta Formation, Argentina". In: Sedimentary Geology 396, p. 105521. DOI: 10.1016/j.sedgeo.2019.105521.

Romanek, Christopher S, Grossman, Ethan L, and Morse, John W (1992). "Carbon isotopic fractionation in synthetic aragonite and calcite: effects of temperature and precipitation rate". In: Geochimica et cosmochimica acta 56.1, pp. 419-430. DOI: 10.1016/0016-7037 (92)901426.

Ronov, AB, Khain, VE, Balukhovsky, AN, and Seslavinsky, KB (1980). "Quantitative analysis of Phanerozoic sedimentation". In: Sedimentary Geology 25.4, pp. 311-325. DOI: 10.1016/0037$0738(80) 90067-6$.

Rooney, Alan D, Cantine, Marjorie D, Bergmann, Kristin D, Gómez-Pérez, Irene, Al Baloushi, Badar, Boag, Thomas H, Busch, James F, Sperling, Erik A, and Strauss, Justin V (2020). "Calibrating the coevolution of Ediacaran life and environment". In: Proceedings of the National Academy of Sciences 117.29, pp. 16824-16830. DOI: 10.1073/pnas. 2002918117.

Rothman, D.H., Hayes, J.M., and Summons, R.E. (2003). "Dynamics of the Neoproterozoic carbon cycle". In: Proceedings of the National Academy of Sciences 100.14, pp. 8124-8129. DOI: $10.1073 /$ pnas . 0832439100.

Saltzman, Matthew R (2005). "Phosphorus, nitrogen, and the redox evolution of the Paleozoic oceans". In: Geology 33.7, pp. 573-576. DOI: 10.1130/G21535.1.

Schidlowski, Manfred, Eichmann, Rudolf, and Junge, Christian E (1975). "Precambrian sedimentary carbonates: carbon and oxygen isotope geochemistry and implications for the terrestrial oxygen budget". In: Precambrian Research 2.1, pp. 1-69. DOI: 10.1016/0301-9268(75) 90018-2.

Schlager, Wolfgang, Reijmer, John JG, and Droxler, AW (1994). "Highstand shedding of carbonate platforms". In: Journal of Sedimentary Research 64.3b, pp. 270-281. DOI: 10.1306/ D4267FAA-2B26-11D7-8648000102C1865D. 
Schoene, Blair (2014). "4.10 - U-Th-Pb Geochronology". In: Treatise on Geochemistry (Second Edition). Ed. by Heinrich D. Holland and Karl K. Turekian. Second Edition. Elsevier, pp. 341378. DOI: $10.1016 /$ B978-0-08-095975-7.00310-7.

Scholle, Peter A and Arthur, Michael A (1980). "Carbon isotope fluctuations in Cretaceous pelagic limestones: potential stratigraphic and petroleum exploration tool". In: AAPG Bulletin 64.1, pp. 67-87. DOI: 10.1306/2F91892D-16CE-11D7-8645000102C1865D.

Schrag, Daniel P, Berner, Robert A, Hoffman, Paul F, and Halverson, G.P. (2002). "On the initiation of a snowball Earth". In: Geochemistry, Geophysics, and Geosystems 300. DOI: 10.1029/2001GC000219.

Schrag, Daniel P, Higgins, John A, Macdonald, Francis A, and Johnston, David T (2013). "Authigenic carbonate and the history of the global carbon cycle". In: science 339.6119, pp. 540-543. DOI: 10.1126/science.1229578.

Skulan, Joseph, DePaolo, Donald J., and Owens, Thomas L. (1997). "Biological control of calcium isotopic abundances in the global calcium cycle". In: Geochimica et Cosmochimica Acta 61.12, pp. 2505-2510. DOI: 10.1016/S0016-7037 (97)00047-1.

Staudigel, Philip T. and Swart, Peter K. (2019). "A diagenetic origin for isotopic variability of sediments deposited on the margin of Great Bahama Bank, insights from clumped isotopes". In: Geochimica et Cosmochimica Acta 258, pp. 97-119. DOI: 10.1016/j.gca.2019.05.002.

Swanson-Hysell, Nicholas L, Maloof, Adam C, Condon, Daniel J, Jenkin, Gawen RT, Alene, Mulugeta, Tremblay, Marissa M, Tesema, Tadele, Rooney, Alan D, and Haileab, Bereket (2015). "Stratigraphy and geochronology of the Tambien Group, Ethiopia: Evidence for globally synchronous carbon isotope change in the Neoproterozoic". In: Geology 43.4, pp. 323-326. DOI: 10.1130/G36347.1.

Swart, Peter K (2008). "Global synchronous changes in the carbon isotopic composition of carbonate sediments unrelated to changes in the global carbon cycle". In: Proceedings of the National Academy of Sciences 105.37, pp. 13741-13745. DOI: 10.1073/pnas.0802841105.

Swart, Peter K and Eberli, Gregor P (2005). "The nature of the $\delta^{13} \mathrm{C}$ of periplatform sediments: Implications for stratigraphy and the global carbon cycle". In: Sedimentary Geology 175.1-4, pp. 115-129. DOI: $10.1016 / \mathrm{j}$. sedgeo.2004.12.029.

Tang, Jianwu, Dietzel, Martin, Böhm, Florian, Köhler, Stephan J, and Eisenhauer, Anton (2008). " $\mathrm{Sr}^{2+} / \mathrm{Ca}^{2+}$ and ${ }^{44} \mathrm{Ca} /{ }^{40} \mathrm{Ca}$ fractionation during inorganic calcite formation: II. Ca isotopes". In: Geochimica et Cosmochimica Acta 72.15, pp. 3733-3745. DOI: 10.1016/j .gca. 2008.05 .033$.

Tziperman, E., Halevy, I., Johnston, D. T., Knoll, A. H., and Schrag, D. P. (2011). "Biologically induced initiation of Neoproterozoic snowball-Earth events". In: Proceedings of the National Academy of Sciences 108.37, pp. 15091-15096. DOI: 10.1073/pnas.1016361108.

Urey, Harold C (1947). "The thermodynamic properties of isotopic substances". In: Journal of the Chemical Society (Resumed), pp. 562-581. DOI: 10.1039/JR9470000562.

Urey, Harold C, Aten Jr., A.H.W., and Keston, Albert S (1936). "A concentration of the carbon isotope". In: The Journal of Chemical Physics 4.9, pp. 622-623. DOI: 10.1063/1.1749918.

Vahrenkamp, Volker C, Swart, Peter K, and Ruiz, Joaquin (1991). "Episodic dolomitization of late Cenozoic carbonates in the Bahamas; evidence from strontium isotopes". In: Journal of Sedimentary Research 61.6, pp. 1002-1014. DOI: 10 .1306/D4267825-2B26-11D78648000102C1865D.

Walker, James CG, Hays, PB, and Kasting, James F (1981). "A negative feedback mechanism for the long-term stabilization of Earth's surface temperature". In: Journal of Geophysical Research: Oceans 86.C10, pp. 9776-9782. DOI: doi.org/10.1029/JC086iC10p09776.

Wanninkhof, Rik (1985). "Kinetic fractionation of the carbon isotopes ${ }^{13} \mathrm{C}$ and ${ }^{12} \mathrm{C}$ during transfer of $\mathrm{CO}_{2}$ from air to seawater". In: Tellus B 37B.3, pp. 128-135. DOI: $10.1111 / \mathrm{j} .1600-$ 0889.1985.tb00061.x. 
Westerhold, Thomas, Marwan, Norbert, Drury, Anna Joy, Liebrand, Diederik, Agnini, Claudia, Anagnostou, Eleni, Barnet, James SK, Bohaty, Steven M, De Vleeschouwer, David, Florindo, Fabio, et al. (2020). "An astronomically dated record of Earth's climate and its predictability over the last 66 million years". In: Science 369.6509, pp. 1383-1387. DOI: 10.1126/science. aba6853. 